\title{
Pintoras y escultoras en el Museo de Arte Moderno de Madrid. Sus exposiciones entre 1898 y 1936
}

\section{Exhibitions of women painters and sculptors at the Museo de Arte Moderno in Madrid (1898-1936)}

\author{
Isabel Rodrigo Villena \\ Universidad de Castilla-La Mancha
}

Fecha de recepción: 22 de abril de 2019

Fecha de aceptación: 25 de marzo de 2020

\section{RESUMEN}

El presente artículo estudia las exposiciones de pintoras y escultoras realizadas en el Museo de Arte Moderno de Madrid desde su inauguración el 1 de agosto de 1898 hasta la Guerra Civil. Revelará los nombres de las doce artistas que tuvieron la oportunidad de exponer en sus salas, analizando las circunstancias que posibilitaron sus muestras y la recepción crítica de sus obras. Incidiremos con ello en la modernidad y la profesionalización que llegaron a alcanzar las artistas mujeres en el primer tercio del siglo XX, a pesar de los fuertes prejuicios sobre el talento femenino y las resistencias generales a la emancipación de la mujer propias de la época.

\section{PALABRAS CLAVE}

Museo de Arte Moderno de Madrid. Artistas Mujeres. Crítica de Arte.
Anuario del Departamento de Historia y Teoría del Arte

vol. 32, 2020, pp. 97-122

ISSN: $1130-5517$, eISSN: 2530-3562

https://doi.org/10.15366/anuario2020.32.005

\begin{abstract}
This article studies the exhibitions of women painters and sculptors held at the Museo de Arte Moderno in Madrid between the inauguration of this institution on August $1^{\text {st }} 1898$ and the Spanish Civil War in 1936. It reveals the names of the twelve women artists who had the opportunity to exhibit in its rooms, analysing the circumstances that made it possible and the critical reception of their works. This analysis shows the relevance, the modernity and the professionalization that women artists reached in the first third of the $20^{\text {th }}$ century, despite the strong prejudices about female talent and the general resistance to women's emancipation in the patriarchal society of that time.
\end{abstract}

\section{KEY WORDS}

Museum of Modern Art (Madrid). Women Artists. Art Criticism. 


\section{Introducción}

Tras años de demandas de tipo gremial por parte de los artistas para dotar de un espacio expositivo adecuado a la colección contemporánea del Museo del Prado, el 4 de agosto de 1894 se crea por Real Decreto el Museo de Arte Contemporáneo ${ }^{1}$, primero de este tipo en España, que venía a corregir el desinterés de los poderes públicos por el arte de su tiempo y el retraso respecto a otras naciones europeas en la creación de una institución específica para tal fin² .

Inspirado en el Museo de Luxemburgo de París y en su idea de promocionar el arte realizado en la propia época por artistas vivos ${ }^{3}$, solo un año más tarde de su fundación, un Real Decreto publicado el 26 de octubre de 1885 cambió su nombre por el de Museo de Arte Moderno (MAM), dando a la naciente institución una orientación más conservadora, que incluía también a los artistas fallecidos posteriores a Goya y restaba al Estado parte de su compromiso de organizar muestras representativas del mismo período ${ }^{4}$.

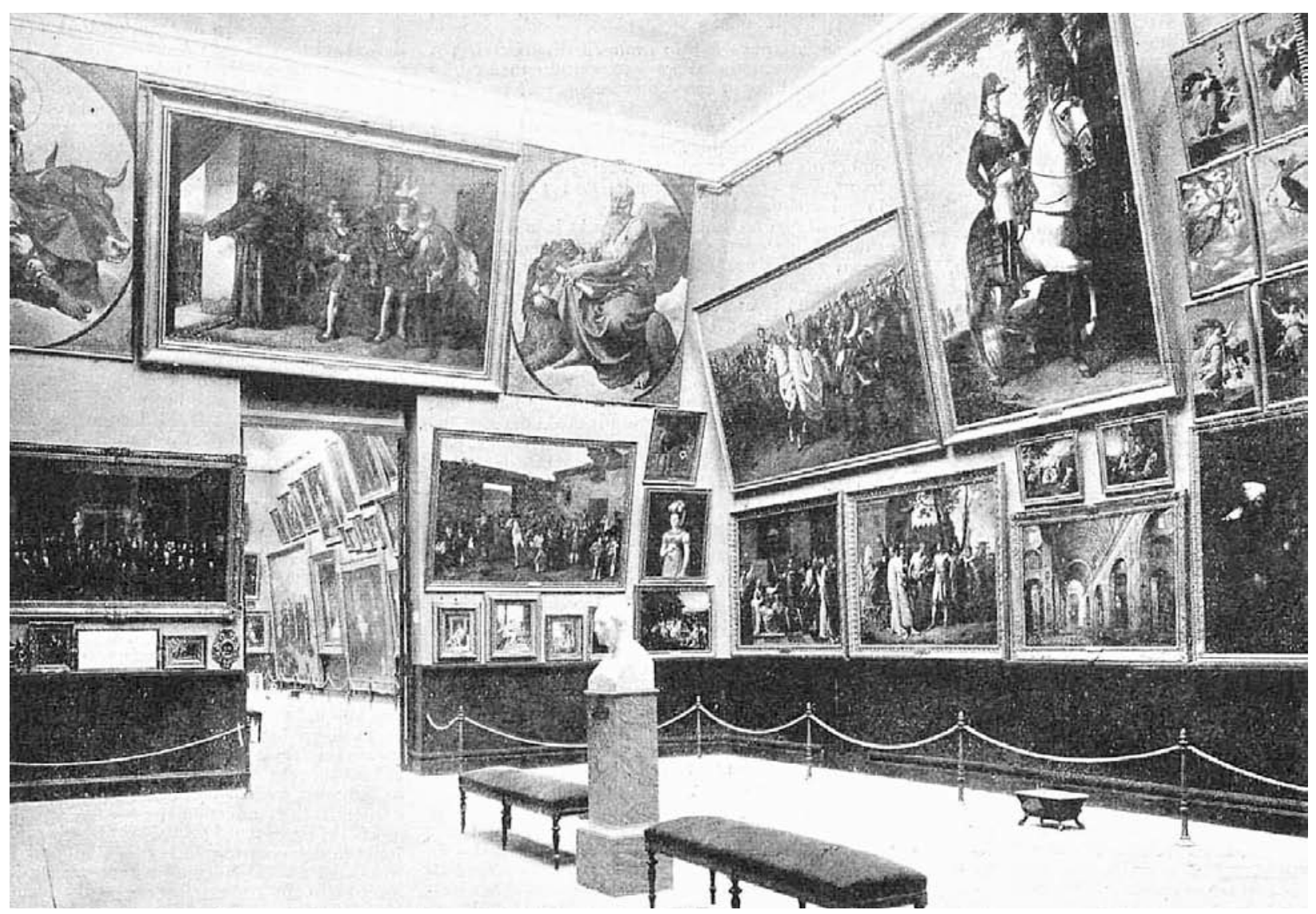

Fig. 1. Sala primera del Museo de Arte Moderno en 1898. Fotografía. La Ilustración Española y Americana, 15-8-1898, p. 84.

1 Sobre el Museo de Arte Moderno véanse: Álvaro Martínez Novillo, El Museo de Arte Contemporáneo Español, Madrid, Ministerio de Cultura, 1984; Elena Vozmediano, "La vieja historia del Museo de Arte Moderno", Espacio, Tiempo y Forma. Serie Historia del Arte, 4 (1991), pp. 377-392; M. a Dolores JiMÉnEZ-Blanco, Arte y Estado en la España del siglo XX, Madrid, Alianza, 1989; y M. a Dolores JiMÉnEZ-Blanco, El coleccionismo de arte en España. Una aproximación desde su historia y su contexto, Barcelona, Fundación Arte y Mecenazgo, 2013.

2 JimÉnEZ-Blanco, 2013, p. 52.

3 Jesús P. Lorente, Los museos de arte contemporáneo. Noción y desarrollo histórico, Gijón, Trea, 2008, pp. 107-108.

4 Martínez Novillo, 1984, p. 6; JimÉnez-Blanco, 1989, p. 19. 
Al carácter retardatario con que nacía el Museo de Arte Moderno, cuya inauguración oficial tuvo lugar el 1 de agosto de 1898 (fig.1), se sumaba un problema no menos importante que complicaría aún más la situación: su falta de espacio dentro del Palacio de Bibliotecas y Museos, donde también se ubicaron la Biblioteca Nacional, el Museo Arqueológico Nacional y el Archivo Histórico ${ }^{5}$. Para rentabilizar las salas asignadas al MAM, se permitió la dispersión de la colección -que para 1899 ascendía a 781 pinturas y esculturas $^{6}$ - a través de depósitos en los Museos Provinciales y se fijó el límite de adquisición a las obras donadas o premiadas en las Exposiciones Nacionales, todo lo cual favoreció aún más la idea de una institución que nacía caduca y academicista, sufriendo fuertes críticas de los artistas y la intelectualidad de la época que le achacaron la ausencia de un plan de adquisiciones autónomo con presupuesto propio, la falta de críticos y artistas jóvenes en su Patronato y, en definitiva, la escasa representación del arte actual ${ }^{7}$.

Durante los años veinte, el Museo de Arte Moderno inició un proceso de transformación que le reportó cierta dignificación de la mano de su quinto director, Mariano Benlliure ${ }^{8}$, quien ejerció el cargo entre 1917 y 1931, compaginándolo con el de Director General de Bellas Artes entre 1917 y 1919. Lo más significativo de su actuación fue la cubrición del patio para ejercer de salón de esculturas, y la dotación de dos salones en la planta baja, en los que poder celebrar una exposición en primavera y otoño, cediendo el resto del año la sala a los artistas para realizar muestras temporales de sus obras. Desde su fundación hasta 1920 solo se habían organizado en el Museo tres exposiciones individuales, dedicadas al pintor inglés David Roberts (1901) y a los españoles Emilio Sala (1911) y Evaristo Valle (1919); además de una exposición de Medallas de Artistas Franceses (1920). A partir de 1921, Mariano Benlliure inició un programa expositivo continuado a lo largo del año, que se sostuvo ya hasta el cierre de la institución durante la Guerra Civil, pasando por sus salas a partir de dicha fecha 196 exposiciones $^{9}$, de las cuales 154 fueron individuales ${ }^{10}$, destacando entre las colectivas las de los artistas becados en El Paular y otros destinos, o las dedicadas al grabado español y europeo.

Pese al nuevo rol de centro activo que iría adquiriendo el Museo de Arte Moderno a partir de los años veinte y a las exposiciones de algunos artistas cercanos al arte nuevo durante este período, la institución no corrigió su desapego al arte más renovador hasta el período republicano, en que ocupó la dirección Juan de la Encina (conocido pseudónimo de Ricardo Gutiérrez Abascal), que era uno de los grandes nombres de la crítica de arte española y muy popular por el tono polémico con que se dirigía a las instituciones oficiales. En el contexto de una renovada política de Bellas Artes, Encina intentó mejorar la presentación de la colección permanente y renovar las colecciones incorporando algunas obras de la vanguardia, sin lograr, sin embargo, que entraran nombres fundamentales que ya estaban presentes en algunos museos europeos, como Picasso, ni dotar a la colección de un edificio apropiado, para cuyo diseño en 1933 se convocó un

\footnotetext{
5 Vozmediano, 1991, p. 382.

${ }^{6}$ Dato recogido en el Catálogo provisional del Museo de Arte Moderno. Segunda Edición Oficial, Madrid, Imprenta del Colegio Nacional de Sordomudos, 1900.

7 En 1916, José Francés arremetía contra la "ramplonería" del Museo, argumentando lo siguiente: "Deben ustedes convencerse de que el actual e indiscutible renacimiento se debe a la juventud no á los autores del 90 por 100 de los mamarrachos pictóricos y escultóricos que se almacenan en el Museo llamado de "Arte Moderno"'. En el mismo sentido, Juan de la Encina escribía en la revista Hermes: "Una vuelta por las salas del museo de arte moderno de Madrid basta para formarse una idea clara de lo que ha sido el arte de esos artistas-políticos de campanario". José FrancÉs, El Año Artístico 1916, Madrid, Mundo Latino, 1916, pp. 47-48 y Juan de la ENCINA, "Las tendencias del arte español contemporáneo", Hermes, 6 (junio 1917), pp. 383-386.

8 Antecedieron a Benlliure: Pedro de Madrazo, José Fernández Díaz y Alejandro Ferrant, prosiguiéndole hasta su cierre temporal durante la Guerra Civil, Eduardo Chicharro y Juan de la Encina. Sobre el papel de Benlliure en el Museo, véase Leticia Azcue, "La dimensión oficial de Benlliure y su vinculación a la Administración”, en L. Enseñat y L. Azcue, Mariano Benlliure. El dominio de la Materia, Madrid, Dirección General de Patrimonio Histórico, 2013, pp. 115-123.

9 Las fechas de exposiciones y el recuento de todas las realizadas en el período analizado se ha obtenido utilizando la Cronología elaborada por la Real Asociación Amigos del Museo Nacional Centro de Arte Reina Sofía, [en línea]: https:/www.amigosmuseoreinasofia.org/enciclopedia_cronologia.php?idArticulo=341 [Consulta: 25 de marzo de 2020].

$10 \mathrm{Al}$ no ser estrictamente exposiciones colectivas, se han contabilizado como exposiciones individuales las realizadas en pareja.
} 
concurso nacional de arquitectura ganado por Fernando García Mercadal, quedando el proyecto truncado tras el estallido de la guerra ${ }^{11}$.

Dentro de este panorama, la participación de pintoras y escultoras en el Museo de Arte Moderno merece un capítulo propio debido a las interferencias de los roles de género que posicionaban de un modo diferente a las mujeres frente a las instituciones y corrientes culturales y artísticas ${ }^{12}$. Paralelo al aumento de mujeres en muchos de los ámbitos sociales y laborales que anteriormente tenían vetados, el incremento de pintoras y escultoras profesionales a lo largo del primer tercio del siglo XX constituye una de las formas en que una España anclada aún en el conservadurismo empezó a poner en práctica la modernidad europea $^{13}$. Acomodando su deseo y su vocación al rol tradicional que no dejó de exigirse a la mujer durante todo el período, una minoría femenina residente en las grandes ciudades logró participar en los mismos ámbitos de experiencia y aprendizaje artístico que los hombres, matriculándose en las escuelas superiores de bellas artes, que incrementaron la presencia femenina desde el 7\% en 1915 al 20\% en 1930, tomando los datos de la Escuela de San Fernando ${ }^{14}$. Los prejuicios sobre las artistas mujeres, consideradas por muchos como un grupo amateur de inferior calidad, lastrado por la práctica de la acuarela y la pintura de flores de sus antecesoras durante el siglo XIX, favoreció la invisibilidad y la escasa atención de la crítica de arte sobre las pintoras y escultoras activas en el circuito artístico, que solo en el caso excepcional de ganar alguna medalla en las Exposiciones Nacionales, o en el no menos difícil caso de lograr exponer individualmente en algún local de prestigio o institución oficial, como el Museo de Arte Moderno, recibían efímera y puntual publicidad. Es en este sentido que la participación femenina en el programa expositivo del MAM, reducida a 11 muestras de las 199 exposiciones que se realizaron desde su fundación hasta 1936, cobra su significado, debido a la proyección pública que proporcionó de manera individual a cada autora, y de forma general, al colectivo de artistas mujeres.

La prensa artística ha sido fundamental para documentar y analizar la trascendencia de dichas exposiciones femeninas, debido a que el archivo del MAM, hoy en la sede del Museo Nacional Centro de Arte Reina Sofía (MNCARS), solo conserva datos administrativos del período analizado. Se ha recurrido, por tanto, a las revistas de arte y a las columnas artísticas de los diarios para recuperar noticias relativas a los actos de inauguración, las obras expuestas, la afluencia de público, así como la valoración crítica de las 12 expositoras, que presentaremos a continuación en el orden cronológico en que se celebraron sus muestras.

\section{Eva Preetsman Aggerholm: primera expositora en el Museo de Arte Moderno}

La exposición del matrimonio formado por Eva Aggerholm (Sæby, Dinamarca, 1879 - Madrid, 1959) y Daniel Vázquez Díaz se puede considerar un hito en la historia del Museo. Celebrada desde el 26 de marzo hasta el 21 de abril de 1921, suponía una apuesta inesperada de Benlliure por el arte moderno, y además presentaba a la primera expositora mujer, que además era escultora, una especialidad escasamente practicada por las artistas mujeres ${ }^{15}$. Se ha sugerido, de hecho, que esta artista danesa, formada primero

\footnotetext{
11 Sobre la política del Museo en esta etapa, véase, de forma más específica, M. a Dolores JiMÉNEZ-BLANCO, “Juan de la Encina, director del Museo de Arte Moderno", en M. Alzuri y M. a D. Jiménez-Blanco, Juan de la Encina y el arte de su tiempo, Madrid y Bilbao, Ministerio de Cultura, MNCARS y Museo de Bellas Artes de Bilbao, 1998, pp. 43-72.

12 Susan KirkPATRicK, Mujer, modernismo y vanguardia en España (1898-1931), Madrid, Cátedra, 2003, p. 21.

13 Ibidem, p. 222.

14 Miguel FigueroA-SAaVedra, "La estudiante de Bellas Artes y la generización masculina del artista creativo", Nueva Antropología, 72 (2010), p. 128, citado en Isabel TEJEDA y M. ${ }^{a}$ Jesús FolCH, A contratiempo. Medio siglo de artistas valencianas. 1929-1980, Valencia, IVAM (catálogo de la exposición celebrada desde el 26 de abril-2 de septiembre), 2018, p. 83.

15 Sobre las escultoras y sus difícultades en este período, véase Isabel RoDRIGO, "Escultoras en un mundo de hombres y su fortuna en la crítica de arte española (1900-1936)", Arenal, vol. 25, 1 (2018), pp. 145-168.
} 
en el campo del dibujo y la pintura en la Academia de Bellas Artes de Copenhague, pudo haberse decantado por la escultura para buscar un espacio propio y diferenciado de Daniel Vázquez Díaz ${ }^{16}$, a quien conoció en París, formándose en el estudio de Bourdelle. En dicha especialidad, se caracterizó por la simplicidad de los volúmenes y una serenidad próxima a lo clásico.

Eva Aggerholm y Daniel Vázquez Díaz se casaron el mismo año en que el artista de Huelva se consagraba como pintor en la Galería Chevalier (1910), regresando juntos a España en 1919. En nuestro país, y pese a compartir similares intereses estéticos, la trayectoria de Aggerholm fue casi anecdótica en comparación a la de Vázquez Díaz; algo por otro lado previsible, siendo la autora mujer, casada y con un hijo en común. Realizó envíos a las Exposiciones Nacionales, consiguiendo premios menores en las ediciones de 1920 y 1929 y una medalla de segunda clase en $1942^{17}$. También participó en ámbitos más renovadores, como el Salón de Otoño $(1920,1935)$ y en las exposiciones de la Sociedad de Artistas Ibéricos (Copenhague, Berlín y París). Sin embargo, ninguno de estos premios y ocasiones expositivas le propiciaron tanta publicidad como su paso por el Museo, donde expuso, entre otras piezas, Rafaelito, Cleopatra, Magdalena, Pureza, Monumento a los Padres y El ángel del dolor (fig. 2).

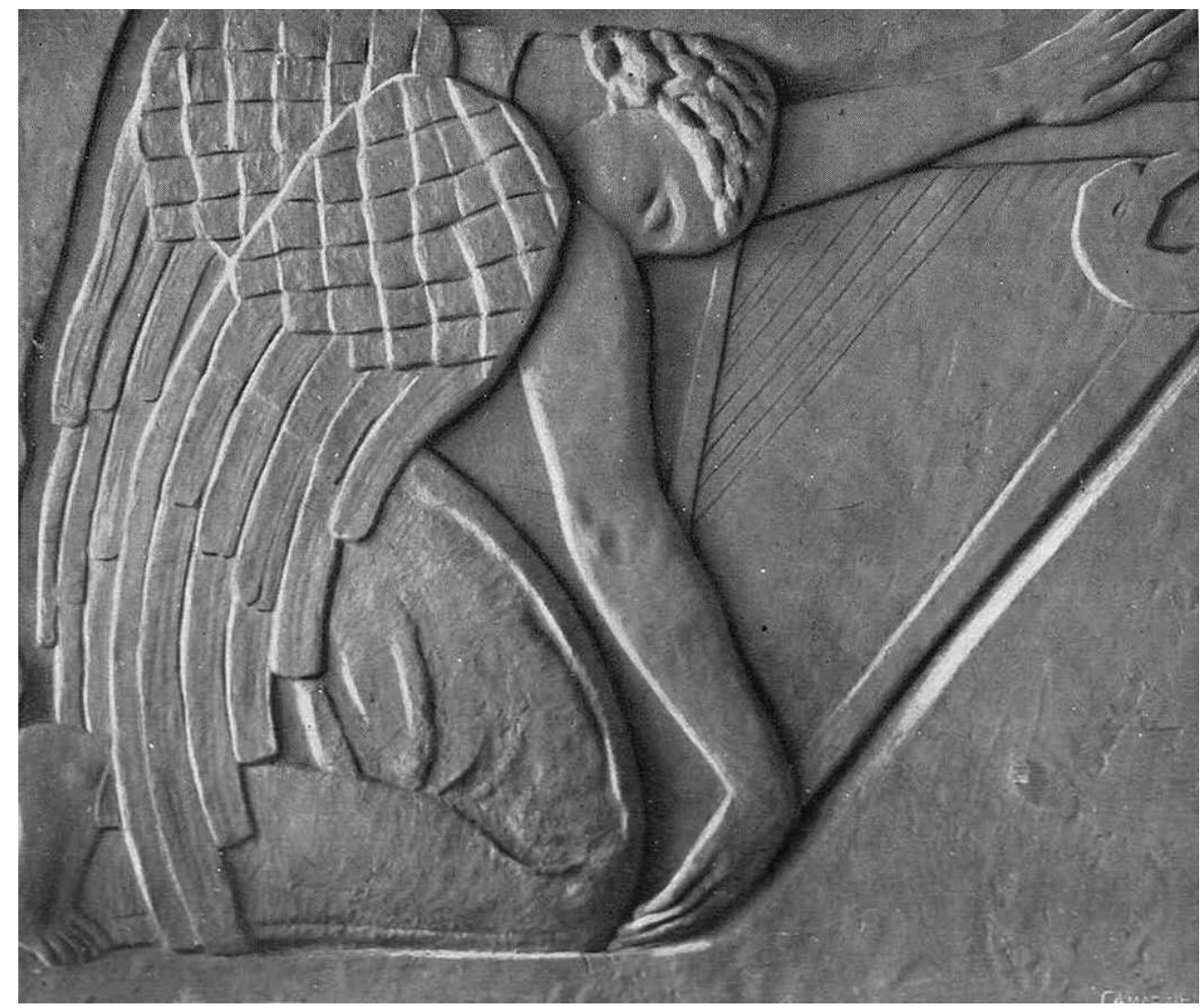

Fig. 2. Eva Aggerholm. El ángel del dolor. Relieve. La Esfera, 7-5-1921, p. 6.

16 Ángel Benito, Vázquez Díaz y la pintura, Madrid, Ministerio de Educación y Ciencia, 1971, p. 86, y Manuel GARCíA-ViÑó, Vázquez Díaz, Madrid, Ministerio de Educación y Ciencia, 1978, p. 27.

17 Véase Bernardino de PANTORBA, Historia y crítica de las exposiciones nacionales de Bellas Artes, Madrid, Jesús Ramón García-Rama, 1980, pp. 245 y 275. 
Sin ser ella el centro de atención principal, del paso de Eva Aggerholm por el MAM hablaron algunos escritores y críticos militantes de la renovación del arte español en la época, que resaltaron la oportunidad de ver y de poder valorar reunidas esculturas que siempre se habían mostrado dispersas y algunas inéditas ${ }^{18}$; lamentaron la ausencia de sus dibujos y sus ensayos pictóricos que, a juicio de José Francés, eran "notas íntimas, finas, de exaltación luminosa"19; y, en general, destacaron la modernidad de su propuesta y la extraordinaria sensibilidad y emotividad puesta en ella. Sobre este último aspecto, Juan Ramón Jiménez, autor del catálogo de la muestra, que tituló (Ideas para un) /Prólogo/ (urgente), escribía: "ella corre toda por dentro; es la plena y rica rama oculta, la sensualidad ideal, el corazón lleno, la meditación de la entraña emotiva" 20 . Para José Francés, el suyo era "un arte noble, hondo, armonioso, creado por una mujer de extraordinaria sensibilidad, como si compusiera versos" ${ }^{21}$.

No eran grandes elogios. O al menos no eran palabras que singularizaran a Eva Aggerholm frente a otras mujeres artistas de su generación, de todas las cuales, y solo por ser mujeres, la crítica se empeñaba en recalcar lo referido a su innata sensibilidad, minusvalorando los aspectos que definían su maestría técnica $^{22}$. Algo más lejos de estos prejuicios, Margarita Nelken insistió en la ciencia existente detrás de la simplificación de sus formas; si bien, por agasajarla, masculinizó su talento como era costumbre, al escribir lo siguiente: "lo menos que puede decirse de Eva Aggerholm es que su escultura, por su integridad y su energía es, a pesar de la ternura de su meditación, obra de hombre" ${ }^{23}$. Una de las críticas menos sesgadas por el género fue la escrita por Juan Ramón, quien hacía notar el intercambio de influencias entre la pareja. En su opinión, el misticismo de Eva había contagiado a Vázquez Díaz, complementándose ambos, pero "siendo cada uno perfectamente desierto y original" 24.

La exposición del matrimonio de artistas fue un éxito para algunos. La revista Ultra organizó para celebrarlo una comida homenaje en el Hotel Excelsior ${ }^{25}$, a la que Eva Aggerholm debió asistir por puro compromiso, porque las fuentes la describen "escéptica para las medallas, los honores y el reconocimiento de su arte" y volcada al cuidado de su familia y de su arte sin preocuparse de la vida social ${ }^{26}$. En cambio, para otros fue un fracaso de asistencia y crítica. García Maroto lamentaba en la revista Índice el vacío realizado a Vázquez Díaz por quienes, apostando aparentemente por la renovación del arte español, seguían reticentes a las novedades ${ }^{27}$. Lo mismo opinaba Nelken, quien criticó que no se hubiera apreciado y valorado la novedad trascendental que ambos temperamentos traían al arte español del momento. Añadía, además, que la celebración de una exposición conjunta había perjudicado específicamente a la escultora: "De haber hecho sola su exposición, Eva Aggerholm se nos aparecería

\footnotetext{
18 José FrancÉs, "Una escultora danesa. Eva Aggerholm”, La Esfera, 383 (7 de mayo de 1921), p. 6.

19 José FrAncÉs, “La exposición Vázquez Díaz: II. Una escultora danesa: Eva Aggerholm”, en El Año Artístico 1921, Madrid, Mundo Latino, 1922, p. 78.

20 Juan Ramón JimÉnez, “Eva Aggerholm de Vázquez Díaz”. Texto reproducido en Ángel CresPo, Juan Ramón y la pintura, Salamanca, Universidad de Salamanca, 1999, pp. 221-222.

21 FRANCÉS, 1922, pp. 78-79.

22 Sobre la crítica de arte a las artistas mujeres durante el mismo período, véanse Isabel RoDRIGO, "Crítica de arte y polémicas de género en la España del primer tercio del siglo XX”, en Actas del XVII Congrés Nacional d'Història de l'Art.CEHA (Barcelona, 22-26 de septiembre de 2008), Granada, Atrio, 2017, pp. 1242-1256; Pilar MuÑoz, "Las mujeres como creadoras en las artes plásticas según los textos de hombres y mujeres en la España de la primera mitad del siglo XX”, Arenal, 2 (2012) pp. 393-413 [en línea], http://www.ugr.es/ arenal/articulo.php?id=195 [Consulta: 12 de octubre de 2017]; Isabel RoDRIGO, "La galantería: una forma de sexismo en la crítica del arte femenino en España (1900-1936)”, Asparkia, 31 (2017), pp. 147-166, http://dx.doi.org/10.6035/Asparkia.2017.31.9.

23 Margarita Nelken, “Artistas modernos. Daniel Vázquez Díaz y Eva Aggerholm”, Cosmópolis, 31 (julio de 1921 ), p. 151.

24 Juan Ramón JimÉnEz, “Eva Aggerholm de Vázquez Díaz”. Reproducido en CRespo, 1999, pp. 221-222.

25 “Arte y Artistas. Banquete en honor a Vázquez Díaz y Eva Aggerholm”, $A B C$ (18 de mayo de 1921), p. 21.

26 Francisco Garfias, Vida y obra de Daniel Vázquez Díaz, Madrid, Ibérico Europea de Ediciones, 1972, p. 15; y Teresa JIMÉNEZ Land, Vázquez Díaz, Madrid, Ministerio de Cultura (catálogo de la exposición celebrada en mayo-julio de 1982), 1982, p. 15.

27 Gabriel García Maroto, “Color y Ritmo. Falta de atención”, Índice, 1 (1921), p. 13.
} 
como uno de los escultores más importantes 1legados a nosotros en estos últimos años"28. No carecía de razón. Daniel Vázquez Díaz volvía a exponer en el Museo en 1927 y fue vocal de su Patronato durante la República. Aggerholm no volvió a sus salas y apenas se la ha recordado como la esposa del pintor ${ }^{29}$.

\section{Las pintoras rusas: Victoria de Malinowska y Maroussia Valero Kotowich}

Mediados los años veinte, en un momento en que la profesionalización de las artistas alentada por el progreso relativo de sus derechos y libertades iniciado tras la I Guerra Mundial empezaba a ser una reali$\mathrm{dad}^{30}$, se produjeron de forma intermitente, pero ya continuada, las exposiciones de mujeres en el MAM, siendo las dos primeras las muestras de dos pintoras rusas que llegaron a España en circunstancias diferentes, compartiendo también una figuración de tintes afrancesados, muy del gusto de críticos como José Francés o Antonio Méndez Casal y de la línea de intereses de Benlliure, todos los cuales defendían lo moderno pero eran contrarios a los experimentos de vanguardia.

La primera en hacerlo fue Victoria de Malinowska (Polonia, activa entre 1918-1952), que expuso desde el 19 de diciembre de 1925 hasta el 1 de enero de 1926. Se trata de una artista injustamente olvidada pese a haber conseguido exponer individualmente en varios lugares de prestigio de Madrid, como el Círculo de Bellas Artes (1918), el Salón Iturrioz (1919), los Patios del Ministerio de Estado (1920), el Ritz (1922) y el Museo de Arte Moderno (1925). Realizó también algunas muestras en el Salón de Artistas Vascos de Bilbao y San Sebastián, lugar donde residió entre 1918-1919, pintando algunos retratos de mujeres vascas faenando $^{31}$, en la misma línea regionalista que Valentín de Zubiaurre ${ }^{32}$ e Ignacio Zuloaga, amigos de la pintora. Este último la inmortalizó en París en un famoso retrato llamado Retrato de Madame Malinowska (La Rusa) (1912) que fue adquirido por el MAM en 1929.

Pese a este currículum poco frecuente en una artista mujer, apenas han trascendido datos de su vida. Por la prensa sabemos que era ruso-polaca y autodidacta, y que había viajado y visitado los museos de diferentes lugares de Europa (Varsovia, San Petersburgo, Berlín, etc.) antes de instalarse en París. A España debió llegar en torno a 1915, huyendo de la Guerra Mundial como otros pintores polacos, y permaneció en nuestro país al menos durante una década, durante la que debió vivir con escasos medios al principio, y más adelante con cierta holgura, logrando enviar dinero a su familia gracias a la venta de retratos en los círculos de la alta sociedad madrileña ${ }^{33}$. Este mercado condicionó su obra. Sus retratos, bodegones y paisajes, resueltos en gamas claras y a veces atrevidas, tenían un resabio de Gauguin, del fauvismo ${ }^{34}$ y del postimpresionismo francés ${ }^{35}$, que poco a poco iría perdiendo, aclimatándose a los rea-

28 NelKen, julio de 1921, p. 151.

29 El MNCARS reunió la obra de ambos en una exposición celebrada entre febrero y mayo del año 2000. Véase Daniel Vázquez Díaz y Eva Aggerholm en las colecciones del Reina Sofía de Madrid, Juan Barba (comis.), Nerva-Huelva, Centro de Arte Moderno y Contemporáneo Daniel Vázquez Díaz (catálogo de la exposición celebrada de febrero a mayo de 2000 ), 2000.

30 Concha LomBA, "El umbral hacia la libertad. Artistas españolas entre 1900 y 1926", en Pintoras en España 1859-1926. De María Luisa de la Riva a Maruja Mallo, Magdalena Illán Martín y Concha Lomba (comis.), Zaragoza, Universidad/Diputación de Zaragoza (catálogo de la exposición celebrada del 20 de febrero al 28 de junio de 2014), 2014, p. 51.

31 Ibidem, 2014, pp. 60 y 63.

${ }^{32}$ La amistad entre Malinowska y Valentín de Zubiaurre se remonta, al menos, a 1917, año del que data un retrato realizado a la pintora, que fue reproducido en el n. ${ }^{\circ} 5$ de la revista Hermes. En 1918, Malinowska presentó en el Círculo de Bellas Artes el Retrato de Pilar Zubiaurre, hermana del pintor. Véase: "Muestras de arte en España", Revista AVGVSTA, Buenos Aires, 3 (agosto 1918 ), p. 69.

33 Declaraciones de la propia artista en: "Una pintora polaca. Victoria de Malinowska", Voluntad, 6 (1 de febrero de 1920$)$, p. 9.

34 Mikel LertXund, Victoria de Malinowska. Pequeñas pescadoras en Ondaroa. Gordailua. Centro de Colecciones Patrimoniales de Guipúzcoa [en línea], https://artsandculture.google.com/asset/peque\%C3\%B1as-pescadorasen-ondarroa/TQFIHaFXXO6ymw?hl=es [Consulta: 23 de julio de 2018].

35 Isabel GARCÍA, "Presencia del arte extranjero en Madrid entre 1915-1922. Artistas procedentes de Europa", en Orígenes de las vanguardias en Madrid (1009-1922), Tesis Doctoral, Universidad Complutense de Madrid, Madrid, 2003, pp. 96-104. 


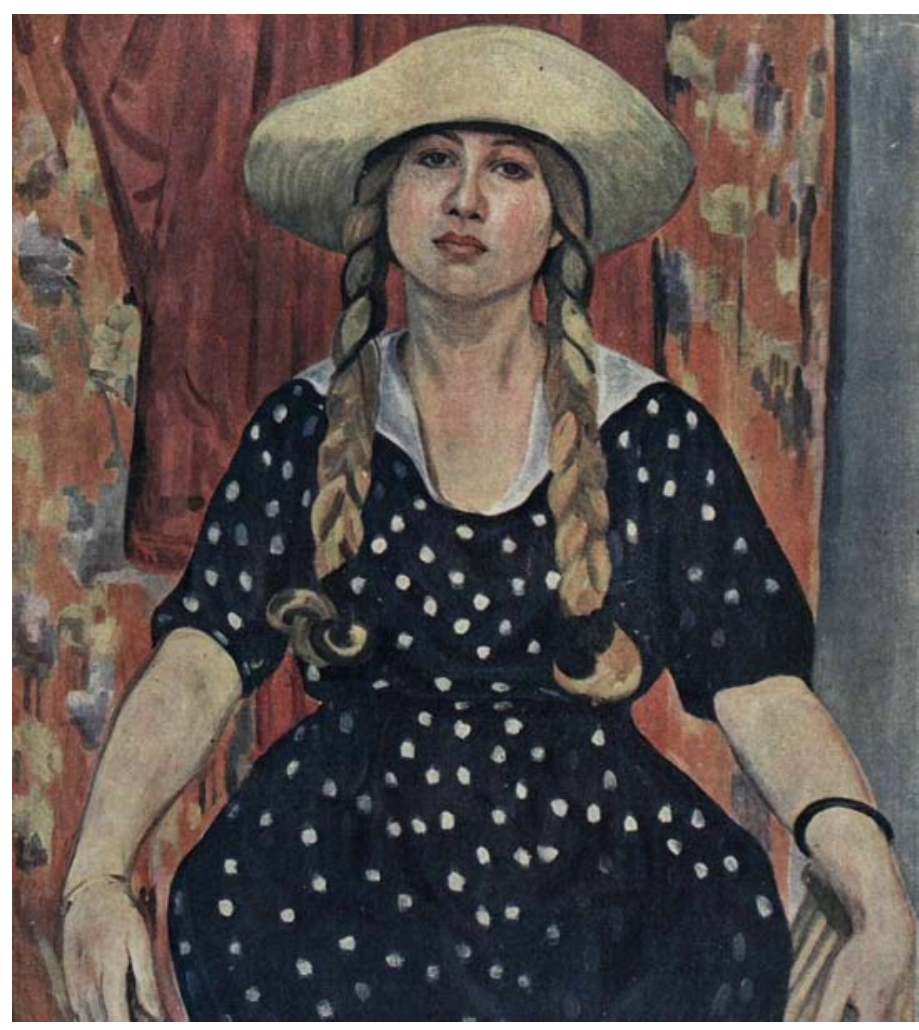

Fig. 3. Victoria de Malinowska. Retrato de señorita. Pintura al óleo. La Esfera, 8-6-1918, portada. infantil ${ }^{40}$, la apuesta de 1925 tampoco terminó de convencerle, reprochándole en esta ocasión que mostrara obras de estilos tan dispares que casi parecían realizadas por artistas diferentes. Entre las obras más modernas, el crítico de $A B C$ señaló su Autorretrato ${ }^{41}$. En cambio, los más adeptos a la pintora, destacaron su "agilísima mano", con rasgos y trazos rápidos y colores suaves que compensaban su "deliberado desdibujamiento"42.

Más allá de 1926 poco sabemos de esta artista. Además de su muestra en el Museo, participó en la Exposición Nacional con los óleos Una polonesa e Interior ${ }^{43}$. Su rastro se pierde a partir de estas fechas. Pudo volver a San Sebastián, o instalarse en Bayona, porque en 1952 participó en la III Exposición de Artistas Franceses de L'Union Bayonnaise des Arts ${ }^{44}$, celebrada en San Sebastián.

Mucho más conocida que la anterior, debido a sus vínculos españoles, es la segunda pintora rusa que expuso en el MAM solo unos meses más tarde. Nos referimos a Maroussia Valero Kotowich (San Petersburgo, 1888 - Barcelona, 1955), hija del tenor sevillano Fernando Valero y de la soprano rusa Raia Kotowich, que inauguró

36 LOMBA, 2014, p. 63.

37 "Un té", Heraldo de Madrid (19 de enero de 1925), p. 4.

38 "Exposición Victoria de Malinowska", La Época (19 de diciembre de 1925), p. 3.

39 "Arte y Artistas", $A B C, \mathrm{n}^{\circ}$ extraordinario (1 de enero de 1926), p. 33.

40 Rafael DoméNeCh, "Exposiciones de Arte", $A B C$ (27 de junio de 1918), p. 6. El mismo texto en: "Una pintura notable", Blanco y Negro, 1417 (14 de julio de 1918), p. 7.

${ }^{41}$ Rafael Doménech, "Exposiciones de Arte", $A B C$ (2 de enero de 1926), p. 6.

42 "Exposición de la pintora polaca Victoria de Malinovska", La Voz de la Mujer, 114 (12 de diciembre de 1925), p. 1.

${ }^{43}$ La autora participó también en las ediciones de 1917 y 1924 de la Exposición Nacional de Bellas Artes y en las de 1923 y 1924 del Salón de Otoño.

${ }^{44}$ Tercera Exposición de artistas franceses de la 'L'Union Bayonnaise des Arts'. Catálogo, San Sebastián, 1952, p. 3. 
su muestra el 26 de mayo de 1926. Maroussia Valero nació en San Petersburgo y recibió sus primeras lecciones artísticas en el taller del pintor polaco Zionglinsky. Una vez instalada la familia en Italia tras la muerte del tenor, amplió su formación en la Escuela de Bellas Artes de Milán, consiguiendo premios en la Academia de Florencia, en la Exposición de Milán y en la Sociedad de Artistas Franceses de París en 1921.

En España, las primeras noticias sobre la autora la sitúan en Barcelona, lugar de veraneo familiar en casa de su abuela, donde en 1909 expuso cuatro trabajos en el establecimiento de música Maristany ${ }^{45}$. En esta época también realizó viajes formativos a Madrid para visitar el Museo del Prado, instalándose en la capital tras la caída del régimen zarista. Su periplo expositivo comenzó en 1925 con una muestra de casi 60 obras entre dibujos, pasteles, aguadas y óleos, en la recién inaugurada Sala Easo ${ }^{46}$, donde mostró escenas de maternidad y tocador ${ }^{47}$; sus muy populares retratos de cupletistas, bailarinas, andaluzas y gitanos; además de retratos de artistas e intelectuales como los músicos Fernández Arbós y Juan Ruiz Casaux, el pintor Néstor o los escultores Victorio Macho y Mariano Benlliure, que dan fe de sus contactos con la intelectualidad española.

Este último ya había organizado una exposición de su hermano, el escultor Fernando Valero, en el Museo, en febrero de 1924, de modo que su muestra en el MAM no debió resultarle demasiado difícil. Sea como fuere, esta exposición pudo ser una decisión precipitada, porque solo colgó 39 trabajos, que en su mayoría eran estudios en pastel para futuros cuadros, debido a lo cual apenas tuvo relevancia en la crítica. Solo Méndez Casal escribió en su defensa que dichos apuntes parecían retratos acabados en sí mismos, resaltando su finura y su "inteligente labor depuradora", al rehusar del "repugnante sentido fotográfico"48 habitual en el género.

Por lo tanto, la consagración de la artista no se produjo en el MAM, sino en la muestra individual que realizó en el Lyceum Femenino en 1928, y mucho más en la realizada en el Círculo de Bellas Artes en 1929, donde colgó 89 obras, añadiendo a sus temas habituales, apuntes de mujeres mucho más modernas y afinadas por el deporte, en las playas italianas, y varios desnudos femeninos de aire erotizado. Aunque no dejó de provocar en los críticos una impresión de improvisación y de abuso del apunte, en esta ocasión la crítica le fue más favorable, destacando sus modernas normas de apreciación y técnica, de factura abocetada y nerviosa de trazos rápidos en sus trabajos más libres, y su capacidad para hacer congeniar exquisitez y elegancia con un trazo enérgico de firmeza constructiva ${ }^{49}$, que daban a su obra un aire viril ${ }^{50}$.

Aunque fueran estas sus exposiciones más renombradas, Maroussia Valero trabajó toda su vida en el campo de la pintura y la ilustración ${ }^{51}$, que complementó con las clases de pintura que impartió a los hijos e hijas de la aristocracia y la alta burguesía madrileñas desde los años veinte ${ }^{52}$. Entre 1932 y 1933 viajó a Los Ángeles para visitar a su hermana Raisa, profesora de canto, llevando algunas de sus obras más folkloristas para abrirse un nuevo mercado, y retrató a diferentes personajes de Hollywood. Quedan de esta época unas fotos muy sugerentes (fig. 4), donde su figura, algo estrafalaria y disidente del aspecto convencional de una mujer burguesa, se confunde con la de sus gitanas ${ }^{53}$. Valero murió

\footnotetext{
45 "Marusa Valero Kotovich", Feminal, 30 (26 de septiembre de 1909), p. 18.

46 Sobre esta exposición: Antonio MÉndez CASAL, “Exposiciones Solís Ávila y Maroussia Valero”, Blanco y Negro, 1783 (19 de julio de 1925), pp. 33-34. José FrancÉs, "Exposiciones en Madrid. Maroussia Valero y Solís Ávila”, La Esfera, 605 (8 de agosto de 1925), pp. 18-19.

${ }^{47}$ Una de estas escenas se publicó en La Esfera, el 2 de enero de 1926. El Museo Bellas Artes de Segovia conserva una obra llamada Retrato de Señorita, muy similar.

48 Antonio Méndez CASAL, “Las últimas exposiciones de primavera”, Blanco y Negro, 1834 (11 de julio de 1926), p. 31.

49 José FrancÉs, "La peligrosa facilidad de Maroussia Valero", La Esfera, 792 (9 de marzo de 1929), p. 39.

50 Antonio Méndez CASAL, "Exposiciones recientes. La de Maroussia Valero”, Blanco y Negro (10 de marzo de 1929$)$, p. 7.

51 Colaboró en Blanco y Negro en 1925 y 1926. Véase Dibujantas. Pioneras de la Ilustración, Marta González y Josefina Alix (comis.) Madrid, Museo ABC (catálogo de la exposición celebrada del 29 de mayo al 29 de septiembre de 219), 2019.

52 Entre ellos estaban Carmen Murillo de Espínola, Carmina Gil Gletga, Carlitos Morla, hijo de diplomático chileno Carlos Morla Lynch, muy amigo de Maroussia; Liu, hija del ministro de China en España; los hermanos Keller; Ana Helfant, etc.

53 Mercedes Replinguer, "Figuras (femeninas) en tránsito", en Dibujantas. Pioneras de la Ilustración, 2019, pp. 27-38.
} 


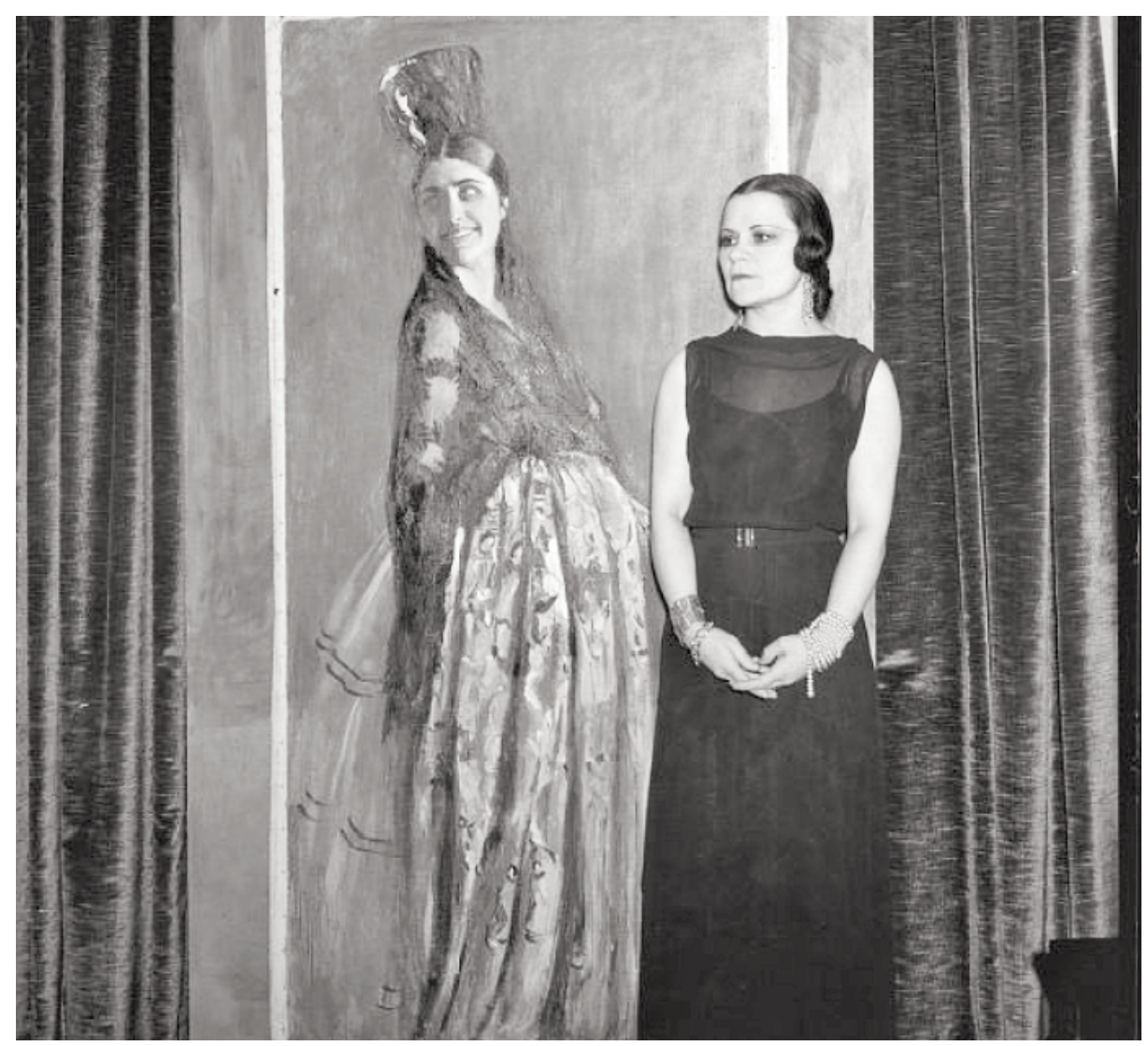

Fig. 4. Maroussia Valero en Los Ángeles, hacia 1932. Fotografía. Los Angeles Times Photographic Archive. Department of Special Collections, Charles E. Young Research Library, UCLA.

de forma dramática junto a su hermana en un escape de gas producido en el domicilio que compartían en Madrid, en 1955.

\section{La exposición de los pintores argentinos Ana Weiss y Alberto Rossi}

Como hicieron tantas mujeres casadas con hombres artistas en la época, la pintora argentina Ana Weiss (Buenos Aires, 1892 - Los Ángeles, 1953) también expuso en el Museo de Arte Moderno acompañada de su esposo, aunque en su caso llegó a España con una reputación previamente adquirida en su país.

Se había formado en la Academia Nacional de Bellas Artes de Buenos Aires, acudiendo también al taller del que sería su futuro marido, el pintor argentino de origen italiano Alberto M. Rossi. Como él, acabó ejerciendo la docencia, después de una trayectoria de ventas de obras al Estado y varios éxitos en los Salones, donde consiguió, entre otros, el Premio Europa para formarse en el Extranjero (1914), que no pudo ejecutar debido al estallido de la I Guerra Mundial; el Tercer Premio Nacional de Pintura en 1926; el Segundo Premio en 1932; el Primer Premio en 1935; y, en 1939, el Gran Premio Adquisición, que por primera vez

\footnotetext{
54 Georgina GluZMAN, "Ilustres y desconocidas. Una moderna madre artista", Revista Ñ Arte, publicado el 4 de octubre de 2018 [en línea], https://www.clarin.com/revista-enie/arte/moderna-madre-artista_0_Ph_oU4rnM.html [Consulta: 23 de julio de 2018].
} 


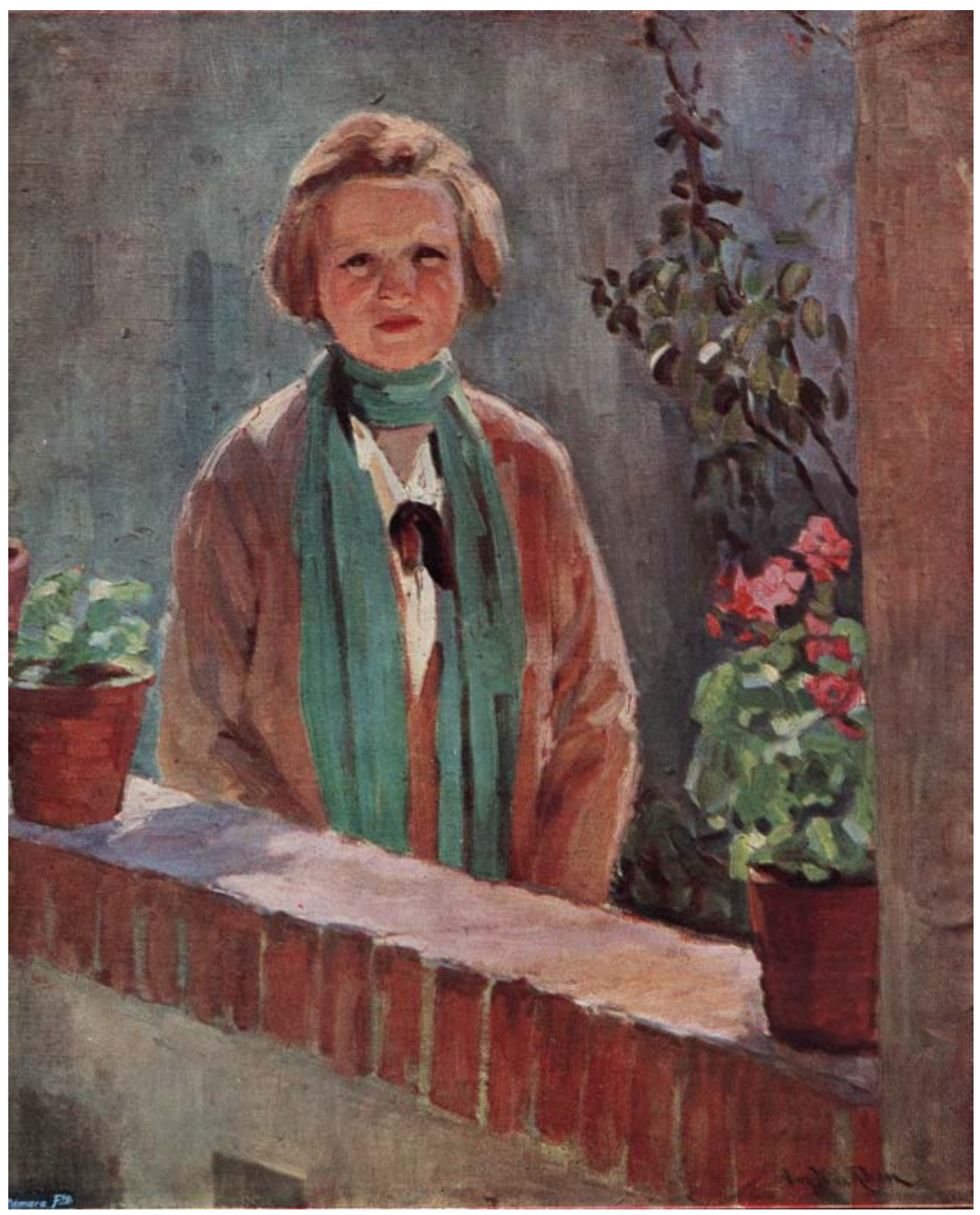

Fig. 5. Ana Weiss. Reflejos del sol. Pintura al óleo. La Esfera, 24-4-1926, p. 17.

recibía una mujer ${ }^{54}$. Durante este recorrido, su pintura fue evolucionando desde una figuración colorista de amplio rango temático hacia un naturalismo centrado en retratos y temas familiares, que acabó propiciándole cierto olvido en la historiografía respecto a compatriotas como Raquel Forner ${ }^{55}$.

La exposición del matrimonio de artistas argentinos en el MAM se inauguró el 4 de mayo de 1929, con el apoyo de la Embajada Argentina en Madrid. Años atrás, ambos habían participado en el I Salón Argentino celebrado en los Amigos del Arte en 1926, resultado del acercamiento cultural entre ambas naciones y del hermanamiento artístico general entre España e Hispanoamérica, impulsado en los años veinte por la sección artística de la Junta de Fomento de Relaciones Hispanoamericanas que, en 1926, acabó posibilitando la participación en igualdad de condiciones en las Exposiciones Nacionales a los artistas pertenecientes a dichas nacionalidades ${ }^{56}$.

55 Georgina GluzMan, "Otras protagonistas del arte argentino: las mujeres artistas en los Salones Nacionales (1924-1939)", Revista do Instituto de Estudos Brasileiros, 71 (2018), p. 62.

56 Rodrigo GUTIÉRREZ ViÑUALES, "Españoles y argentinos. Relaciones recíprocas en la pintura (1920-1930)", en IV Jornadas de Teoría e Historia de las Artes, “Las Artes en el debate del. Quinto Centenario”, Buenos Aires, C.A.I.A., 1992, p. 123. 
Según lo narrado por la prensa, Rossi presentó 16 óleos y Weiss 14, entre los que estaban: Vistiéndose, La hora del té, El abuelo, Niño dormido, El desayuno, Buby, Los hermanitos, Miria Nicasia, En la capilla, Tipos del norte argentino, La hija del pescador, Lejos del pago y Reflejos de sol (fig. 5). La crítica fue amplia, equitativa y favorable para ambos, pero dispar en los juicios sobre cada uno. A Francisco Alcántara le gustó más la propuesta de Ana Weiss, cuyos paisajes y escenas de playa de tradición sorollista eran más luminosos y vibrantes de color ${ }^{57}$. A Eduardo Navarro, al contrario, le pareció que detrás del luminismo mediterráneo de Weiss y de su preferencia por temas familiares e infantiles no había grandes audacias técnicas, que sí hallaba en el esposo, de pintura más afrancesada ${ }^{58}$. La perfecta ensambladura entre el sentimiento y la técnica fue lo resaltado de Weiss por José Francés desde La Esfera, quien también valoraba la difícil independencia creativa de ambos artistas y la fuerza de ella para resistirse a una fácil influencia del maestro ${ }^{59}$.

Junto a esto, Ana Weiss también se vio sometida a juicios que valoraban su obra en relación con los atributos que prejuiciosamente debía cumplir como mujer artista. Méndez Casal, muy dado a hacer estas valoraciones sobre las pintoras en su columna de Blanco y Negro, hablaba de ella como una artista en formación, a pesar de que llevaba más de veinte años dedicándose profesionalmente a la pintura, y recalcaba su papel de madre, señalando que pintaba niños como quien practica su deporte favorito. Al crítico, nombrado vocal del Patronato del Museo ese mismo año, también le asombraba encontrar en ella una calidad técnica equiparable a la de un hombre. En sus propias palabras, su obra se apartaba "del tipo conocido de obra femenina en cuanto a la técnica. Un toque amplio, sin exceso de detalle, dan a cada trazo, aisladamente examinado, aspecto de pintura recia, de pintura varonil" 60 .

\section{Marisa Roësset y Gisela Ephrussi, dos pintoras modernas}

El Salón del Museo de Arte Moderno [...] se despereza y pavonea porque le visitan muchachas modernas y se le adhieren perfumes de buen tono. Los habituales [...] van, vienen, entre los vestidos caros, las risas claras y los mirones recientes ${ }^{61}$.

Con estas palabras describió José Francés el revuelo y la expectación que causó, por estar dedicada a dos mujeres, la muestra conjunta de la pintora madrileña Marisa Roësset de Velasco (Madrid, 1904-1976) ${ }^{62}$ y de la retratista austriaca Gisela von Ephrussi (Viena, 1904-México, 1985), inaugurada en el Museo de Arte Moderno el 2 de diciembre de 1929. Les unía un maestro común, Fernando Álvarez de Sotomayor, y una similar estilización y sistematización de las formas que las acercaba a las nuevas figuraciones europeas, siendo una muestra muy armoniosa y homogénea, en opinión de los críticos ${ }^{63}$. Estos hicieron un seguimiento del evento considerablemente mayor que el de las restantes expositoras, en el que también se juzgaron aspectos anecdóticos relacionados con el aspecto juvenil de las pintoras, con lo exótico de sus nombres, que sonaban a "heroínas de cuento para niños o de novela para novios" ${ }^{64}$, o sobre su estilo de vida moderno. Se escribió, por ejemplo, que a Röesset, que tenía aspecto de sana y bronceada adolescente y pei-

57 "Un matrimonio de artistas argentinos", $A B C$ (2 de mayo de 1929), p. 19.

58 E.N., "Los pintores argentinos Ana Weiss de Rossi y Alberto M. Rossi”, Revista Hispanoamericana de Ciencias, Letras y Artes, 73 (mayo de 1929), pp. 241-243.

59 José FrancÉs, "Dos pintores argentinos. Ana Weiss y Alberto Rossi”, La Esfera, 802 (18 de mayo de 1929), pp. 6-7.

60 Antonio Méndez CAsal, "Exposiciones recientes. La del matrimonio Rossi-Weis”, Blanco y Negro, 1984 (26 de mayo de 1929), pp. 13-14.

61 José FrancÉs, "Marisa Röesset, Gisela Ephrussi”, La Esfera, 833 (21 de diciembre de 1929), p. 26.

62 Tras localizar su partida de nacimiento, Concha Lomba ha resituado la fecha de su nacimiento en el 6 de marzo de 1903. Concha LombA, "Marisa Roësset, en la frontera", Archivo Español de Arte, 362 (abril-junio 2018), p. 148.

63 Germán Gómez de la Mata, “Arte y artistas. Juvenilia”, Crónica, 5 (15 de diciembre de 1929), p. 6. "Exposiciones y noticias artísticas: Marisa Roësset y Gisela Ephrussi”, $A B C$ (3 de diciembre de 1929), p. 24.

64 Ibidem, p. 26. 


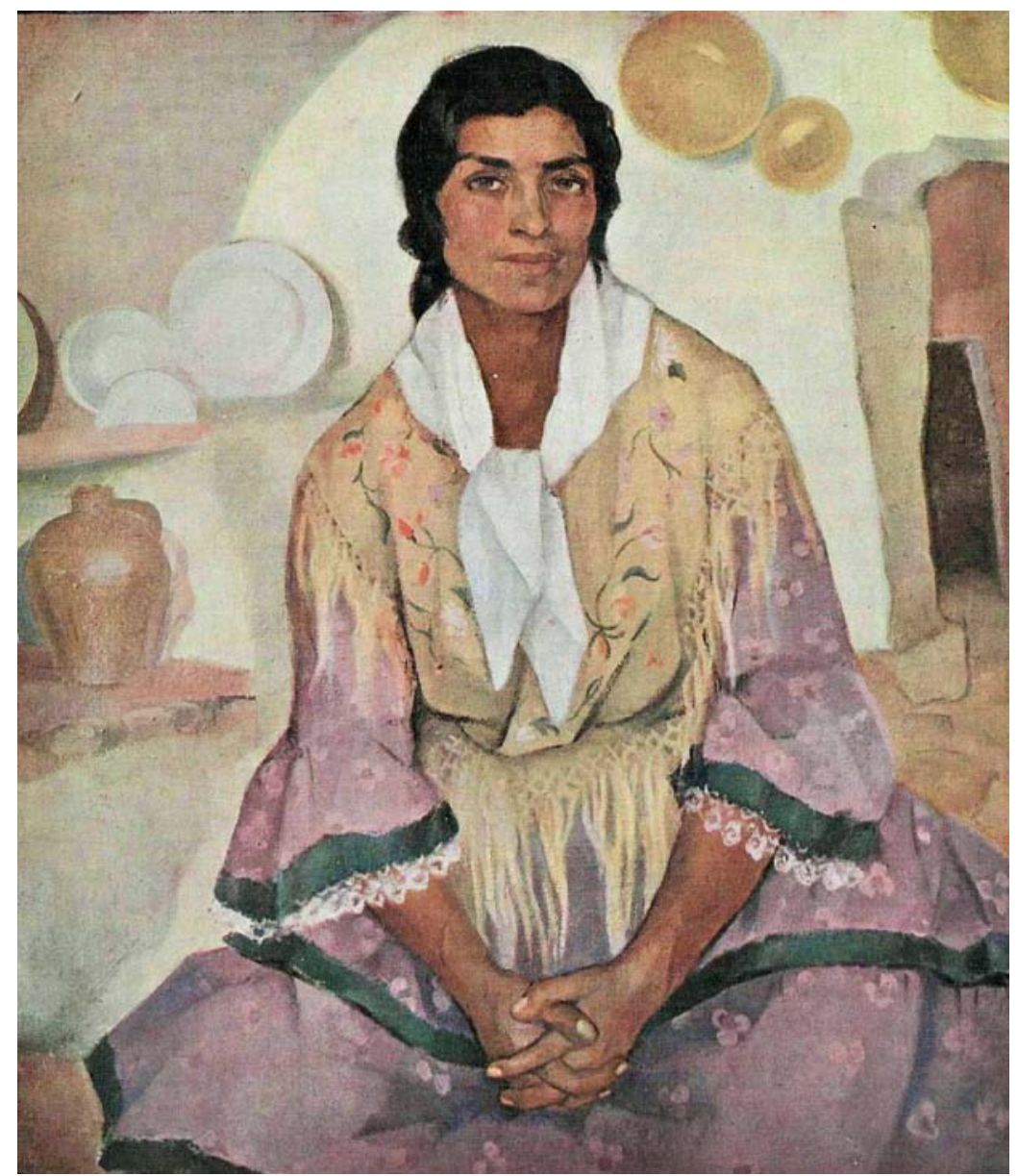

Fig. 6. Marisa Roësset. Una gitana. Óleo. La Esfera, 8-2-1930, portada.

naba un "flequillo muchachil" "65, lo mismo se la podía ver en los cenáculos artísticos que en los bailes de moda y en los clubs deportivos ${ }^{66}$. De Ephrussi, nacida y criada por institutrices en un lujoso palacio vienés, se aplaudió su vocación artística, capaz de dejar a un lado la opulencia y la "frivolidad" de la vida moderna ${ }^{67}$.

De las dos pintoras, el centro de atención principal fue Roësset, que era ya conocida en el ambiente madrileño tras haber expuesto en el Lyceum Femenino en 1927, y mucho más por haber obtenido dos terceras medallas en la Exposición Nacional de 1924 y en la Internacional de Barcelona en 1929. Artista ya profesional, con un taller abierto en la calle Hermosilla, a Marisa Roësset la avalaba también su formación en los estudios de dos prestigiosos y contradictorios maestros: Sotomayor y Vázquez Díaz. Ambos habrían propiciado en su obra una síntesis muy original de lo clásico y lo moderno, según escribieron Luis Gil Fillol ${ }^{68}$, José Francés ${ }^{69}$ o Emiliano Aguilera $^{70}$, sobre a las obras expuestas en la muestra, que fueron 25, principalmente retratos (de marineros, gitanas, toreros, mujeres solas o con niños) y varios autorretratos, desnudos y naturalezas muertas.

\footnotetext{
65 Manuel ABrIL, “Marisa Roësset y Gisela Ephrussi”, Revista de las Españas, 39-40 (noviembre-diciembre de 1929), pp. $421-422$.

66 FrancÉs, 21 de diciembre de 1929, p. 26.

67 Méndez CaSAL, 22 de diciembre de 1929, p. 30.

${ }^{68}$ Luis Gil Fillol, "Marisa Roësset y Gisela Ephrussi”, Estampa, 104 (7 de enero de 1930), p. 21.

69 FrANCÉs, 21 de diciembre de 1929, pp. 26-27.

${ }^{70}$ Emiliano M. Aguilera, “Marisa Roësset y Gisela Ephrussi en el Museo de Arte Moderno”, El Socialista (15 de diciembre de 1929$)$, p. 4.
} 
Todo ello propició un interés por la obra de Roësset mayor y más serio de lo que era habitual para una artista mujer, consiguiendo reportajes en varios magazines, e ilustrar algunas portadas de La Esfera en los meses siguientes a la exposición. En general todos destacaron su capacidad para ser consciente y civilizada, para dominar el instinto y llegar a ser elegante hasta en los motivos más extravagantes, logrando una especie de "gracia reflexiva"71, en palabras de Rafael Marquina. Méndez Casal escribía sobre el mismo aspecto que la obra de Röesset era "intuición encauzada por la inteligencia", porque esquematizaba las formas y los colores y añadía sinfonías cromáticas arbitrarias, sin caer en lo zafio y excéntrico ${ }^{72}$, de lo cual eran ejemplo las obras Autorretrato, Hanny y Guky, Desnudo, Torero, Retrato de T.S.C., Marinero Vasco y Una Gitana (fig. 6). Para José Francés, quien resumió su concepto artístico con la expresión "inteligencia impaciente", la capacidad de Roësset para ser moderna sin someterse a las vanguardias era, además, un logro insólito entre las mujeres, escribiendo con notable desdén respecto a otras artistas:

Aun en nuestro tiempo que le son concedidas garantías y ecos á su capacidad, la mujer artista sigue defraudando, á veces. O estribillo ó flinflán de circo, O cocinera de guisotes recalentados ó víctima contagiosa de los estupefacientes del expresionismo, el montparnasismo y el eslavismo á sueldo estético de los soviets. O el cuadro que las mamás y los maridos burgueses de las mamás comprenden perfectamente o el cuadro que les horroriza $^{73}$.

Al contrario que para Roësset, la exposición en el Museo fue para Gisela Ephrussi su puesta de largo. La joven artista pertenecía a una rica y muy bien posicionada familia de banqueros judíos, tanto por la línea paterna -su padre era Viktor Ritter von Ephrussi, aristócrata y banquero austriaco-, como por su esposo, Alfredo Bauer, uno de los representantes de la influyente banca Rothschild, que se establecieron en España a mediados del siglo XIX y llegaron a ser amigos personales del rey Alfonso XIII y a ocupar puestos en la administración municipal madrileña, en las cortes y el senado. Además de pintora, formada desde los 11 años con David Kohn y en España con Sotomayor ${ }^{74}$, Ephrussi también trabajó como traductora y fue por algún tiempo secretaria de la Universidad Internacional de Verano de Santander ${ }^{75}$.

Del total de su obra, formada por 29 trabajos, que fueron principalmente paisajes y retratos, la crítica destacó sus dibujos a lápiz de escritores e intelectuales-Celaya, Tenreiro, Gabriel Miró-, en cuyos rostros conseguía captar el carácter y la espiritualidad de cada autor. Entre los óleos de mayor penetración psicológica se citaron también el Retrato al padre y su Autorretrato (fig. 7), y se comentaron y reprodujeron otros, como Paisaje de la Alhambra o Mohamed. En conjunto, sin atribuirle los mismos méritos que a Röesset porque era principiante aún, la crítica apreció el vigor de sus formas, compensado por la delicadeza en la aplicación del color ${ }^{76}$. José Francés resumía su estilo escribiendo que sus obras eran de una "sobriedad no seca, de hondura no hueca, de sencillez no pobre, de energía y profunda armonía tonal"77.

71 Rafael Marquina, “Exposición Roësset-Ephrussi”, La Gaceta Literaria, 73 (1 de enero de 1930), p. 12.

72 Antonio MÉndez CASAL, "Exposiciones recientes", Blanco y Negro, 2014 (22 de diciembre de 1929), p. 28.

73 FRANCÉS, 21 de diciembre de 1929, p. 26.

74 Emilia Cortés IBÁNEZ (ed.), Zenobia Camprubi y Olga Bauer: Epistolario 1932-1956, Huelva, Biblioteca de Estudios Juanramonianos, 2017, p. 20.

75 Julián Marías, Una vida presente: Memorias, Madrid, Páginas de Espuma, 2008, pp. 110-111.

76 Marquina, 1 de enero de 1930, p. 12.

77 FrANCÉS, 21 de diciembre de 1929, p. 27. 


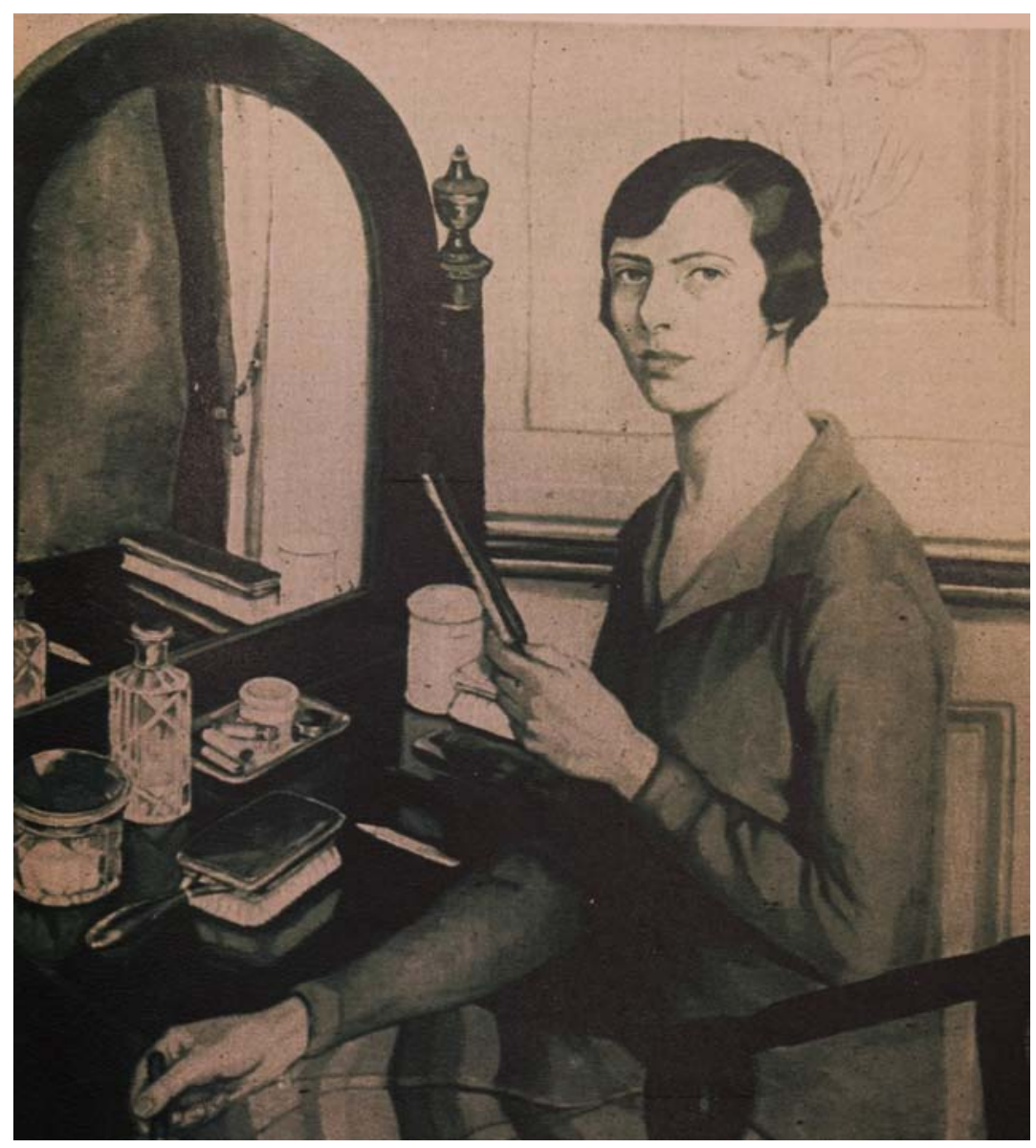

Fig. 7. Gisela Ephrussi. Autorretrato.Pintura al óleo. Blanco y Negro, 15-121929, p. 77.

\section{Las expositoras de 1930: Paula Millán Alosete, Margarita Hausmann y Thyra Ullmann}

En 1930 el Museo de Arte Moderno estuvo cerrado durante los meses de agosto y septiembre, en los cuales se instaló una claraboya de cristal en el patio de la planta baja y una fuente con una escultura de Canova. Pese a ello, además de conferencias y exposiciones colectivas, tuvieron lugar 16 exposiciones individuales, incluidas las dedicadas a las pintoras Paula Millán, Margarita Hausmann y Thyra Ullmann.

El de la primera expositora, la pintora y dibujante Paula Millán Alosete (Madrid, 1899 - 1979), es uno de los casos de artistas mujeres más injustamente silenciados en nuestra historia del arte, porque a pesar de llegar a lo más alto en la ilustración botánica contemporánea española, logrando ser dibujante del Real Jardín Botánico (1933-1969) y profesora de dibujo científico en la Escuela de Estudios Auxiliares de Investigación del CSIC, apenas se la recuerda ${ }^{78}$.

Su inclinación al dibujo científico debió producirse por influencia de su padre, Mario Millán Velasco, que era dibujante en la Cátedra de Anatomía de la Facultad de Medicina de Madrid. La avalaron también

78 Véase Juan Luis CAStillo, "Paula Millán Alosete. Artista botánica española”, Anales del Jardín Botánico de Madrid, 2 (2000), pp. 444-446 y Miguel Cabañas Bravo e Idoia Murga Castro (eds.), Arte en el Jardín Botánico: Patrimonio, memoria y creación, Madrid, Ediciones Doce Calles, 2016, pp. 12-15. 


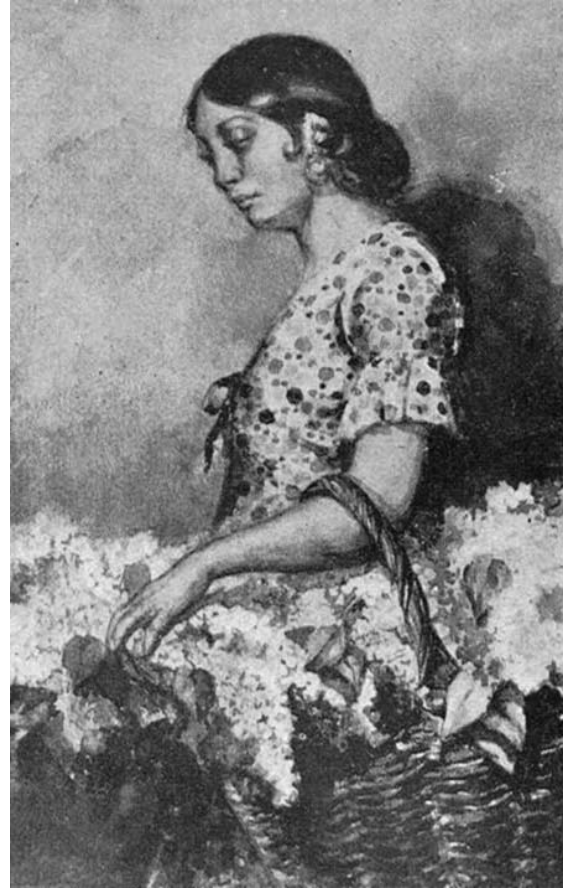

Fig. 8. Paula Millán, Dibujo. Lápiz. La Esfera, 23-3-1930, p. 28. sus estudios universitarios, primero en la Escuela de Artes Cerámicas y después en la Escuela Especial de Pintura, Escultura y Grabado. Quizá se decantó por dicha especialidad debido a las dificultades para sostenerse autónomamente como mujer pintora y dibujante, ámbito en el que Paula Millán probó suerte presentándose a certámenes y exposiciones como el Salón de Otoño (1920, 1924 y 1934), los Salones de Humoristas (IX, XV) y el Círculo de Bellas Artes (1925), donde expuso 50 obras entre retratos, paisajes, escenas de la vida familiar, costumbres ciudadanas y campesinas y tipos populares, realizados al óleo, acuarela y temple ${ }^{79}$. Consta también su trabajo como ilustradora en revistas ${ }^{80}$.

Su exposición en el Museo se realizó desde el 28 de febrero hasta el 15 de marzo de 1930 y, desafortunadamente, solo hemos localizado una reseña escrita por Estévez Ortega en La Esfera. Siguiendo esta fuente, la artista presentó unos 30 dibujos a pluma y 10 acuarelas, casi todos figuras y desnudos (fig. 8). El crítico veía en ella un futuro razonable porque dominaba el dibujo y mostraba seguridad y soltura a un tiempo. "Su dicción es fuerte, sin la dulzonería un poco empalagosa de la acuarela, y sobre todo, de la acuarela de origen femenino" 81 , escribía, tratándola como una excepción frente al colectivo de acuarelistas mujeres, como era habitual.

No sabemos mucho más de la autora tras su paso por el Museo. En 1931 participó en el I Salón de Mujeres Dibujantas en el Lyceum Femenino y en la Exposición de Bellas Artes del Diario Universal y, en 1934, en el Concurso Nacional de Acuarelistas. Su plaza de auxiliar de dibujo científico en el Real Jardín Botánico la llevó a centrarse con mayor exclusividad a la ilustración científica y la docencia.

La segunda expositora del MAM durante 1930 fue la paisajista alemana Margarita Hausmann. Su exposición se inauguró el 18 de junio y fue visitada por la reina Victoria Eugenia ${ }^{82}$, quien adquirió los cuadros Rocas a la salida del sol y Sol del mediodía ${ }^{83}$. No sabemos si la amistad con la reina se trabó en la exposición o era previa a la misma, pero sí que la hubo, porque la pintora fue una de las personalidades presentes en la estación para recibir a la reina en el sudexpreso de Madrid, cuando regresaba de un viaje a Inglaterra en noviembre de $1930^{84}$.

Como en el caso de Paula Millán, la exposición de Hausmann en el MAM pasó desapercibida para la crítica aunque, en su caso, la coincidencia con la Nacional de Bellas Artes y con la clausura de la Exposición Internacional de Sevilla, acontecimientos muy comentados en los meses de junio-julio de ese año, pudieron desviar la atención. Entre las 37 obras expuestas ${ }^{85}$ había paisajes de Mallorca, Barcelona y Marruecos, como Vista desde un café marroquí, Pinos de Vallvidriera, La sombra de los arcos, Calle de Oro, Rocas, Sol de mediodía, Rocas a la salida del sol, Rocas en la cala de Deia, Olivos milenarios, Cala de San Vicente y Por la mañana en la cala. La autora presentaba también algunos retratos que para Criado y Romero, del Heraldo de Madrid, destacaban por su colorido, pero eran más vacilantes y tenían menos

\footnotetext{
79 Francisco AlcÁntara, "Exposición de la señorita Millán Alosete”, El Sol (3 de diciembre de 1925), p. 4.

80 En 1926 ilustra en Lecturas el relato "Conchita Guerra", de José Champsaur.

81 Enrique Estévez OrtegA, "Pintura y caricatura", La Esfera, 487 (23 de marzo de 1930), p. 28.

82 "La familia real y la corte. Visita a una exposición", $A B C$ (20 de junio de 1930), p. 16.

83 "Cuadros adquiridos por Su Majestad la Reina", $A B C$ (27 de junio de 1930), p. 28.

84 "Llegada de la reina y las infantas. El recibimiento en la estación", $A B C, \mathrm{n}^{\circ}$ extraordinario (29 de noviembre de 1930$)$, p. 16.

85 “Exposición Margarita Hausman”, $A B C$ (17 de junio de 1930), p. 39.
} 
vida que sus bellos y deliciosos paisajes, donde se hermanaban "la emotividad y la vida con la ejecución, toda vigor y pujanza" $"$.

Sobre la artista apenas han trascendido datos sobre su vida. Sabemos que había trabajado junto a varios artistas en Dusseldorf y París antes de llegar a España, donde llevaba residiendo cinco años. Aquí, y como otros artistas alemanes, viajó por Mallorca, visitando también la Costa Brava y Marruecos, lugares de los que dejó varias vistas, de colores brillantes y fuertes contrastes de luz. Conocemos también que presentó trabajos a la Exposición de Bellas Artes de Sevilla en $1926^{87}$ y que, entre 1929 y 1930, estuvo activa en Barcelona, donde participó en varias muestras colectivas (I Salón de la Asociación de Pintores y Escultores y I Exposición de la Agrupación de Arte) ${ }^{88}$, y realizó una exposición individual en la Sala Areñas (1929). Al reportero que cubrió este último evento, obra y personaje debieron resultarles muy modernos, siendo descrita como una "atrevida artista que transita por los campos del feminismo y del impresionismo como Pedro por su casa" ${ }^{\text {. }}$.

La última expositora de 1930 fue Thyra Ekwall de Ullmann (Geboren, Suecia, 1881 - Madrid, 1983) que se había formado con su padre, el pintor Knut Ekwall, instalándose en Madrid tras su boda con Guillermo Ullmann, director del Banco Alemán Transatlántico. Ella también debió ser una mujer moderna y deportista, porque estaba inscrita en la Real Sociedad Alpina Peñalara, con quienes realizaba excursiones y practicaba el alpinismo ${ }^{90}$.

La exposición fue inaugurada el 16 de diciembre de 1930 y, dado el estatus de la artista, tuvo cierta relevancia social, siendo visitada por el rey ${ }^{91}$ y festejada después con una cena en el Ritz a la que acudieron más de 100 personas de la alta sociedad madrileña y de la colonia alemana, incluido el embajador, el conde de Welczeck ${ }^{92}$. Presentó 57 obras, entre óleos, pasteles, temples y acuarelas, de los cuales 15 eran retratos y el resto paisajes y cuadros de ambiente. Como elemento más novedoso, la artista incluía también 24 esculturas (Pierrot, Pescador y Jugando al tenis, etc.), casi todas figuritas modeladas con cera de color, junto a alguna escayola y algún bronce.

Entre los medios y críticos que comentaron su obra hubo opiniones diferentes. Para Gil Fillol, desde el diario gráfico Ahora, en la obra de Ullmann dominaba un "espíritu infantil e ingenuo"93, que atribuía al lirismo del romanticismo alemán y a la sinceridad y libertad de un trabajo todavía amateur. No se entendió así en las páginas artísticas del Heraldo de Madrid, donde Miguel Pérez Ferrero, con cierta sorna, escribía que la artista alemana no reflejaba la tradición nórdica como era de esperar y que sus retratos eran universales, pero de "un universalismo de tiendecita de cuadros para renovaciones de casas burguesas y para recuerdos de paisajes bonitos" $" 94$. Mejor crítica recibió en $A B C$, donde se escribió que era una exposición de calidad, con cuadros que mostraban la evolución desde un realismo moderado, de penetración psicológica y bella composición, hasta una mayor sencillez. Solamente se le achacó cierta indefinición en las técnicas y la temática, que se atribuyó, con un argumento puramente sexista, a sus "distintos estados espirituales, merced a cambios tan propios de todo temperamento femenino, impresionable y flexible" 95 . Bien diferente fue la acogida de la artista en La Gaceta Literaria, donde se resaltó la minuciosidad, perfección y franqueza de sus pequeñas esculturas, y el movimiento contenido y domesticado del conjunto de su obra,

\footnotetext{
86 Emilio CriAdo, "Exposición Margarita Hausman”, El Heraldo de Madrid (5 de julio de 1930), p. 15.

87 "Exposición de Bellas Artes", El Sol (23 de marzo de 1926), p. 6.

${ }^{88}$ Francesc FontBona, Repertori de catàlegs d'exposicions collectives d'art a Catalunya (fins a l'any 1938), Barcelona, Institut d'estudis catalans, 2002, p. 182 y 187.

89 "Avances del feminismo. Racha de exposiciones", $A B C$ (15 de febrero de 1929), p. 33.

90 Manuel Mollá, "El grupo de los alemanes y los paisajes de la Sierra de Guadarrama", Boletín de la A.G.E., 59 (2001), p. 61.

91 "El rey en una exposición”, La Vanguardia (16 de diciembre de 1930), p. 16.

92 "Banquete a una artista alemana", $A B C$ (31 de diciembre de 1930), p. 37.

93 Luis Gil Fillol, "Exposiciones de fin de año", Ahora, 15 (1 de enero de 1931), p. 26.

94 Miguel Pérez Ferrero, “Thyra Ullmann Ekwal en el Museo Nacional de Arte Moderno", El Heraldo de Madrid (3 de enero de 1931), p. 8 .
} 
que la hacía muy moderna y acorde con el retorno al orden y los realismos de nuevo cuño defendidos por la revista en aquella época ${ }^{96}$.

Pocos datos más se conocen de la autora en su etapa madrileña. Sabemos que estuvo en la Exposición Nacional de 1934, donde presentó las esculturas decorativas: Nacimiento, Retrato de niña y María entre rosas. En 1936 expuso en la Sociedad Amigos del Arte ${ }^{97}$, trasladándose tras la Guerra Civil a San Sebastián donde continuó pintando hasta su muerte, acaecida en Madrid el 9 de enero de 1983.

\section{El museo en la II República. Las exposiciones de Margarita Frau, Norah Borges y Léonie Matthis}

Durante la Segunda República, y en respuesta a las muchas críticas dirigidas al Museo desde su fundación, su nuevo director, Juan de la Encina, intentará abrir las puertas del Museo al arte contemporáneo universal y nacional, y al arte más actual realizado por autores aún no consolidados, cediendo su espacio expositivo a artistas más jóvenes y renovadores como González Bernal, Pérez Mateo, Benjamín Palencia, Moreno Villa, Rodríguez Luna, Torres García, Quintanilla, Frau, Gargallo o Max Ernst ${ }^{98}$, y las pintoras Margarita Frau y Norah Borges. Ello no evitó que, durante el mismo período, por presiones de los miembros más conservadores del Patronato, se realizaran también varios homenajes a artistas del pasado y exposiciones de autores más academicistas, entre los que estaba nuestra última expositora, la pintora Léonie Matthis.

La exposición de Margarita de Frau (Madrid 1909-1986) junto a su marido y profesor de pintura, José Frau, se celebró desde el 1 hasta el 30 de octubre de 1933. En realidad, se llamaba Margarita González Giraud y tuvo una trayectoria artística muy corta, porque enseguida abandonó la pintura para dedicarse a la familia ${ }^{99}$. En su escaso recorrido, desarrolló una obra acorde a la actualización que vivió el Museo durante la República, que oscilaba entre el paisaje y el bodegón, con una figuración sólida y geometrizante, cercana a la línea "constructivista" de la Sociedad de Artistas Ibéricos (S.A.I) junto a los que expuso en París en $1936^{100}$.

A diferencia de José Frau, que ya tenía dos medallas en la Exposición Nacional (1924 y 1932), y era un miembro activo de la S.A.I desde su creación, el montaje de Margarita Frau en el Museo no interesó a los críticos. Manuel Abril le dedicó un obligado párrafo al final del texto llamado "El poema de José y Margarita" ${ }^{101}$ donde escribía que, pese a ser neófita todavía, tenía buenas cualidades y se veían avances en el oficio en obras como La Anunciación y El abrazo de la hiedra. Algo más extenso, pero emitiendo argumentos impregnados por el sexismo de la época, Estévez Ortega incidía desde Gaceta de Bellas Artes en que la artista se mostraba puramente femenina en la elección de los temas, por componer escenas con sencillos elementos domésticos de su entorno, pero no así en la hechura, por cuya solidez constructiva y ejecución enérgica, precisa y segura, daba la impresión de que "no fueran manos delicadas las que [usaban] los pinceles"102. Del conjunto de sus obras, destacó las llamadas Marina, Caracola, La casa de enfrente y El tren.

95 "Pinturas y esculturas de Thyra Ullmann-Ekwal", $A B C$ (17 de diciembre de 1930), p. 29.

96 S.D. GRANADA, "Thyra Ullmann-Ekwal”, La Gaceta Literaria, 100 (1 de marzo de 1931), p. 7.

97 Luis Gil Fillol, "Thyra Ekwall, pintora y escultora”, Ahora (18 de marzo de 1936), p. 35.

98 JiMÉNEZ-BlANCO, 1989, pp. 36-38. Véase también Jaime BRIHUEGA, "Renovación, vanguardia y avanzada en el meridiano cronológico de la Segunda República”, en J. Pérez Segura e I. García (coords.), Arte y política en España: 1898-1939, Sevilla, Junta de Andalucía, 2002, pp. 14-27.

99 Carmen Dalmau, "La imagen de las mujeres a través de las pintoras españolas durante los años 30 del siglo XX", en M. Almela (dir.), Malas, Madrid, UNED, 2015, p. 211.

100 Manuel ABril, "Exposición Internacional de Arte en París", Blanco y Negro, 2327 (23 de febrero de 1936), pp. 64-65.

101 Manuel ABRIL, "El poema de José y de Margarita", Blanco y Negro, 2212 (5 de noviembre de 1933), p. 62. 
Más que en esta exposición, por la que sus allegados organizaron a Margarita Frau una cena homenaje en el Ritz ${ }^{103}$, la prensa artística se fijó en ella cuando su tela Tinte en plata recibió por unanimidad una tercera medalla en la Exposición Nacional de 1934 (fig. 9). En esta ocasión, Estévez Ortega destacó su inteligencia y su talento pictórico por haberse sabido independizar del estilo del maestro y esposo, haciéndose con un estilo personal caracterizado por poner el mismo empeño en el color y la composición que en la anécdota de los motivos, y dotar a las cosas más inexpresivas e inanimadas de un simbolismo y tono literario genuinos. Estas cualidades la convertían en un caso insólito frente al arte "mediocre" de sus colegas pintoras, como expresaba en un nuevo argumento prejuicioso sobre las artistas mujeres:

Suele adolecer la pintura femenina de cierta blandura, de inevitable afeminamiento; pero en ninguno de estos dos paisajes, vigorosamente construidos y en los que la pincelada tiene un gran vigor, ímpetu expresivo, se advierte la débil y maliciosa factura que suelen tener los cuadros pintados por mano de mujer ${ }^{104}$.

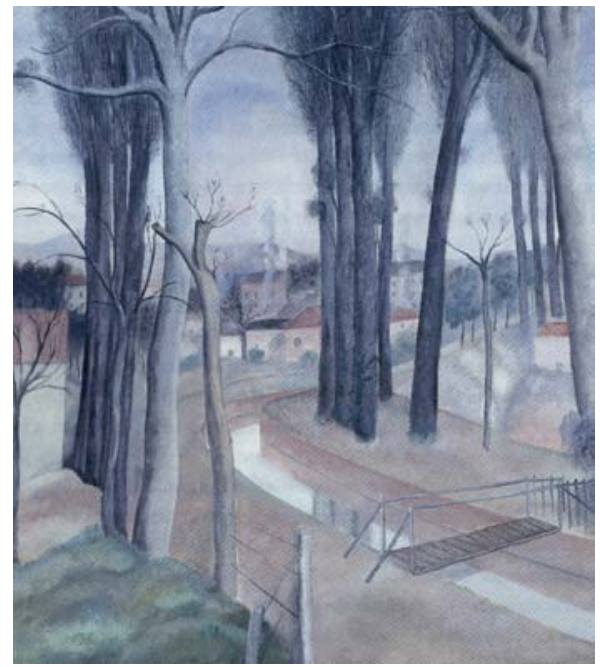

Fig. 9. Margarita Frau. Tinte en plata. Pinuta al óleo. Museo Nacional Centro de Arte Reina Sofía, ca. 1934.

Las últimas obras expuestas por la pintora en España antes de la Guerra Civil se vieron en el Salón de Otoño de 1935, donde colgó los trabajos Interior, Ruinas y Paloma Mensajera, y en la Exposición Nacional de 1936, a la que presentó Rama sin hojas, marchando después al exilio.

A diferencia de Margarita Frau, que expuso en los inicios de su carrera artística, la exposición de la pintora argentina Norah Borges (Buenos Aires, 1901-1998), ya conocida en el panorama del movimiento ultraísta, que había vivido en Mallorca, Sevilla y Madrid entre 1919 y 1921, e ilustrado buena parte de las revistas de la vanguardia española, se produjo en una fase muy diferente de su vida y de su carrera profesional, habiendo realizado ya exposiciones individuales en Buenos Aires. Casada con el poeta y crítico de arte español Guillermo de Torre, ambos habían regresado a España en 1932, animados por la proclamación de la II República, período durante el cual Norah ilustró el libro Júbilos de su amiga Carmen Conde, colaboró en el número 7 de Diablo Mondo y diseñó los figurines de la Égloga de Plácida y Victoriano de Juan de la Encina para el grupo de teatro La Barraca ${ }^{105}$. Este último, amigo de la pareja y director del Museo, organizó en la institución su primera exposición individual en España, que se celebró desde el 16 de febrero hasta el 10 de marzo de 1934, y estuvo compuesta por 42 óleos y dibujos entre los que estaban: Santa Inés y Santa Emerenciana, Urbano y Simona, El Herbario, Tres ángeles, Seis ángeles, Playa, Puerto, Ciudad a orillas del mar, El niño del pájaro, Tres niñas, Tres niños junto al mar, Niña de perfil, Niñita de perfil, Niñita de ojos azules, Sirena, Dos sirenas y El marinero y la sirena (fig. 10).

Debido a que Ramón Gómez de la Serna ${ }^{106}$ y Eduardo Westerdahl ${ }^{107}$ habían publicado amplios textos sobre la obra de Norah Borges tras su regreso a España, su paso por el Museo no generó una crítica amplia.

102 Enrique Estévez OrtegA, "Varias exposiciones interesantes. Margarita y Frau”, Gaceta de Bellas Artes, 428 (noviembre 1933), pp. 19-20.

103 "Agasajo a dos artistas. A la pintora Margarita de Frau", $A B C$ (1 de julio de 1934), p. 49.

104 Enrique Estévez OrtegA, "La Exposición Nacional de Bellas Artes”, Gaceta de Bellas Artes, 434 (mayo-junio 1934 ), p. 27.

105 Roberta Ann QuANCE, "Cronología de Norah Borges, 1914-1940”, Romance Studies, vol. 27, 1 (enero 2009 ), pp. 5-6.

106 Ramón Gómez de la SERnA, "Norah Borges”, Arte, 1 (1932), pp. 20-21.

107 Eduardo Westerdahl, "Norah Borges, Gaceta de Arte, 20 (1933), p. 1. 


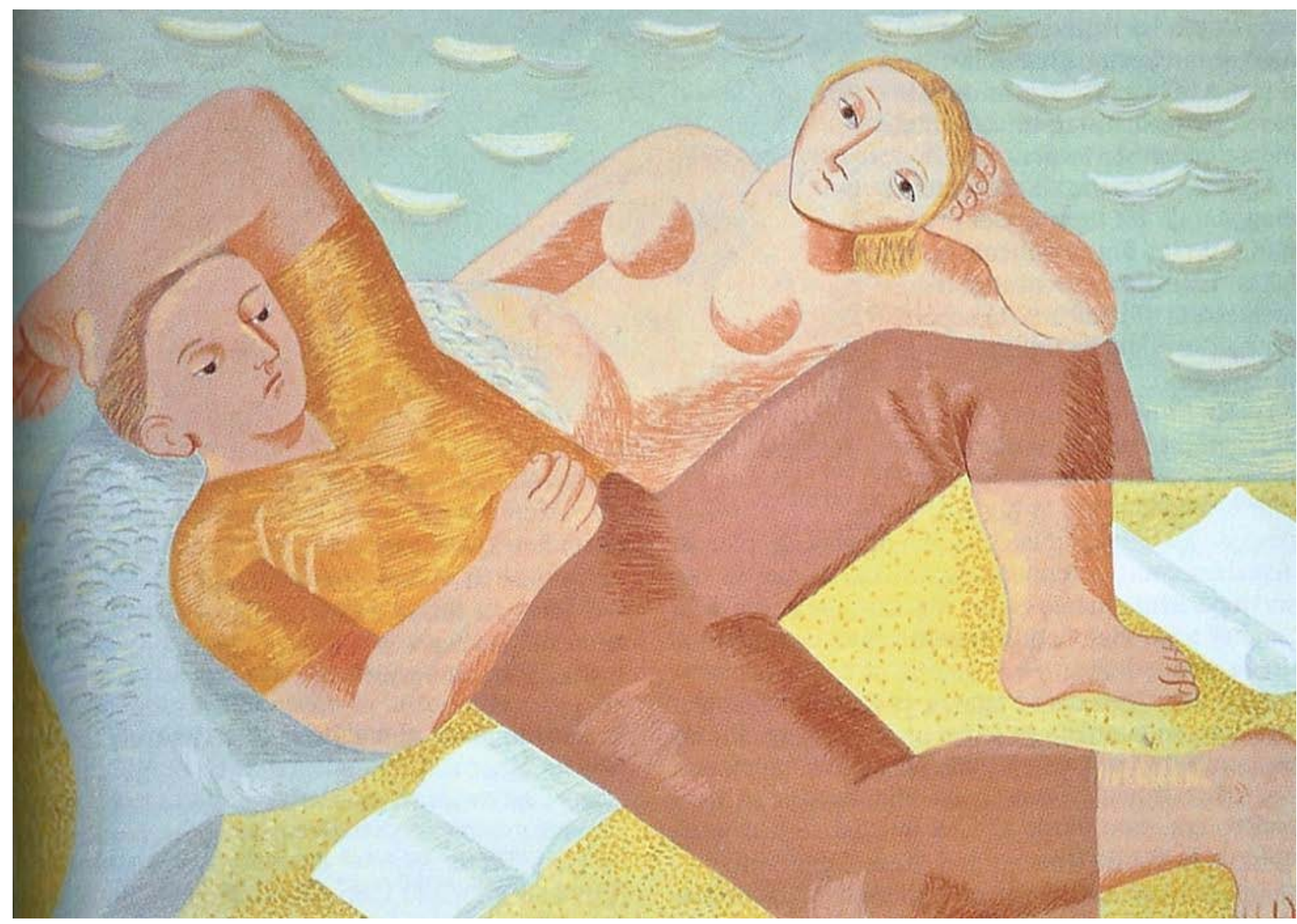

Fig. 10. Norah Borges. El marinero y la sirena. 1931. Témpera sobre papel. Colección Gonzalo de la Torre.

La muestra se anunció en varios medios, entre ellos Gaceta de Bellas Artes ${ }^{108}$. Desde su columna de El Sol, Juan de la Encina animó a visitar la exposición por la oportunidad que ofrecía apreciar un estilo "inconfundible", de expresión absolutamente "nueva y personal"109; un estilo que Manuel Abril situaba en las "falanges de la plástica moderna; pero [de] esa modernidad que en el fondo es tradición de forma y orden" "110. El resto fueron breves reseñas que no evaluaban la trayectoria de la artista, desde sus figuras expresionistas y sus xilografías ultraístas en blanco y negro, a los trabajos de inspiración clasicista que irrumpieron en su obra a mediados de los años veinte por influencia del novecento italiano y Picasso, quedándose en aspectos mucho más superficiales y nada explicativos de la ambigua iconografía de sirenas con faldas, ángeles sin alas y jóvenes andróginos que poblaban su obra ${ }^{111}$; y sin advertir tampoco los nexos americanistas de sus pinturas. Por el contrario, algunos vincularon el lirismo de sus temas con su condición de mujer, limitando el alcance de su obra a los tópicos femeninos de la gracia, el encanto, la ingenuidad, la ternura, la sensibilidad, etc. Sus telas - escribía Manuel Abril en la revista Luz-, eran verso y madrigal, surgidas de su

108 "Informaciones de arte. Exposición de Norah Borges de Torre en el Museo de Arte Moderno", Gaceta de Bellas Artes, 431 (1934, febrero), p. 36.

109 "Exposición de Norah Borges de Torre", El Sol (14 de febrero de 1934), p. 4.

110 Manuel ABriL, "Norah Borges", Luz (19 de febrero de 1934), p. 11.

111 May LoREnZo AlCALÁ, "Norah vanguardista o la construcción de un estilo", en Norah Borges, mito y vanguardia, Museo de Bellas Artes de Neuquén (catálogo de la exposición celebrada de julio a agosto de 2006), 2006, p. 25. 
"alma de adolescente enamorada"112. Todas ellas -explicaba José María Marañón desde El Heraldo de Madrid - destacaban por su "dulce ingenuidad" y su "recatado contenido poético", capaz de establecer comunicación directa con el corazón del espectador"113.

Seguramente, gracias a la publicidad de la muestra en el Museo, Norah Borges apareció también en las páginas del magazín Estampa, donde Emilio Fornet le hizo una pequeña entrevista, acompañada con una fotografía de la pintora en su piso madrileño, que la caracterizaba doblemente como mujer moderna, al presentarla leyendo una revista junto a una mesa repleta de libros y dos esculturas africanas. En ella, Norah Borges ponía énfasis en la imaginación, y explicaba trabajar "por recreación poética de mis sensaciones... Nunca del natural"114.

La última expositora del Museo de Arte Moderno fue la pintora francesa, asentada en Argentina, Léonie Matthis (Troyes, Francia, 1883 - Turdera, Argentina, 1952). Estilísticamente no representaba la modernidad, mostrando una obra de corte más academicista que las anteriores, basada en líneas quebradizas y colores armoniosamente encendidos, usando principalmente la técnica del gouache. En cambio, Matthis fue una mujer moderna; una de las primeras pintoras en ingresar en la Academia de Bellas Artes de París (1898), que viajaba sola para ampliar nuevos horizontes artísticos, y había visitado España en varias ocasiones para pintar su luz y sus arquitecturas. Aquí conoció a Francisco Villar, un pintor asturiano de familia humilde que había emigrado a la Argentina siendo adolescente y estaba realizando una estancia en París desde 1909. Con él se trasladó a Buenos Aires en 1912, formando una familia de la que nacieron nueve hijos.

A diferencia de Villar, más centrado en la representación de tipos autóctonos, Matthis se dedicó al género histórico, acrecentado en la Argentina de finales del siglo XIX y principios del XX, para afirmar una personalidad propia frente a la llegada de la inmigración del viejo continente ${ }^{115} \mathrm{y}$, en cierto modo, para recuperar un pasado idílico preindustrial contrapuesto a la realidad contemporánea ${ }^{116}$. En este género, Matthis fue una de las pintoras más destacadas y comprometidas, que hacía una labor de investigación en archivos, museos y colecciones ${ }^{117}$ a fin de reconstruir los escenarios, los personajes y los hechos tratados, pintando a pie de calle (fig. 11).

Dedicada a la Buenos Aires colonial, la muestra de 32 gouaches que trajo a España y expuso en el Museo en febrero de 1936 era el resultado de toda una trayectoria de obras históricas iniciada en 1923, que iba organizando en series temáticas (Buenos Aires antiguo y moderno; Buenos Aires antiguo y colonial; Evocaciones del pasado, Salta y Jujuy; Historia de la patria a través de la Plaza de mayo, etc.), y había ido mostrando en los espacios de exhibición más importantes de Buenos Aires, sobre todo en la galería Witcomb.

La recepción de su obra en Madrid fue discreta. El catálogo, firmado por A. Pérez Valiente de Moctezuma, atribuía todo el valor a la nostálgica recuperación del "mundo lejano y sin memoria de los abuelos coloniales". En la misma línea, la columna "Arte y Artistas" de $A B C$ recomendaba la visita a la exposición, por la reconstrucción histórica ofrecida en sus estampas, que mostraban un hondo sentir hacia el pasado, poco habitual en "tiempos de pedantería y decadencia"118. A Manuel Abril también le resultó interesante la fuerza sugeridora de las imágenes, en las que no encontraba grandes efectismos, sustituidos por una discreción extraordinaria ${ }^{119}$.

112 Abril, 19 de febrero de 1934, p. 11.

113 José María Marañón, "Norah Borges de Torre”, Heraldo de Madrid (8 de marzo de 1934), p. 8.

114 Emilio Fornet, "Norah Borges. Constructora de ángeles y sirenas", Estampa, 323 (17 de marzo de 1934), pp. 16-17.

115 Rodrigo Gutiérrez, "La Pintura de Historia en la Argentina", Atrio, 8-9 (1996), p. 202.

116 Catalina FARA, "Recuerdos de la 'Gran Aldea'. Usos de imágenes del pasado urbano de Buenos Aires (1910-1936)", Inmediaciones de la comunicación, 2 (2017), pp. 143-144.

117 GutiérReZ, 1996, pp. 197-214.

118 “Arte y artistas. En el Museo Nacional de Arte Moderno. Exposiciones Mauroner y Matthis”, $A B C$ (3 de febrero de 1936), p. 35.

119 Manuel ABRIL, "Novedades de la Quincena. [...] Una pintora argentina", Blanco y Negro, 3226 (16 de febrero de 1936), p. 98. 


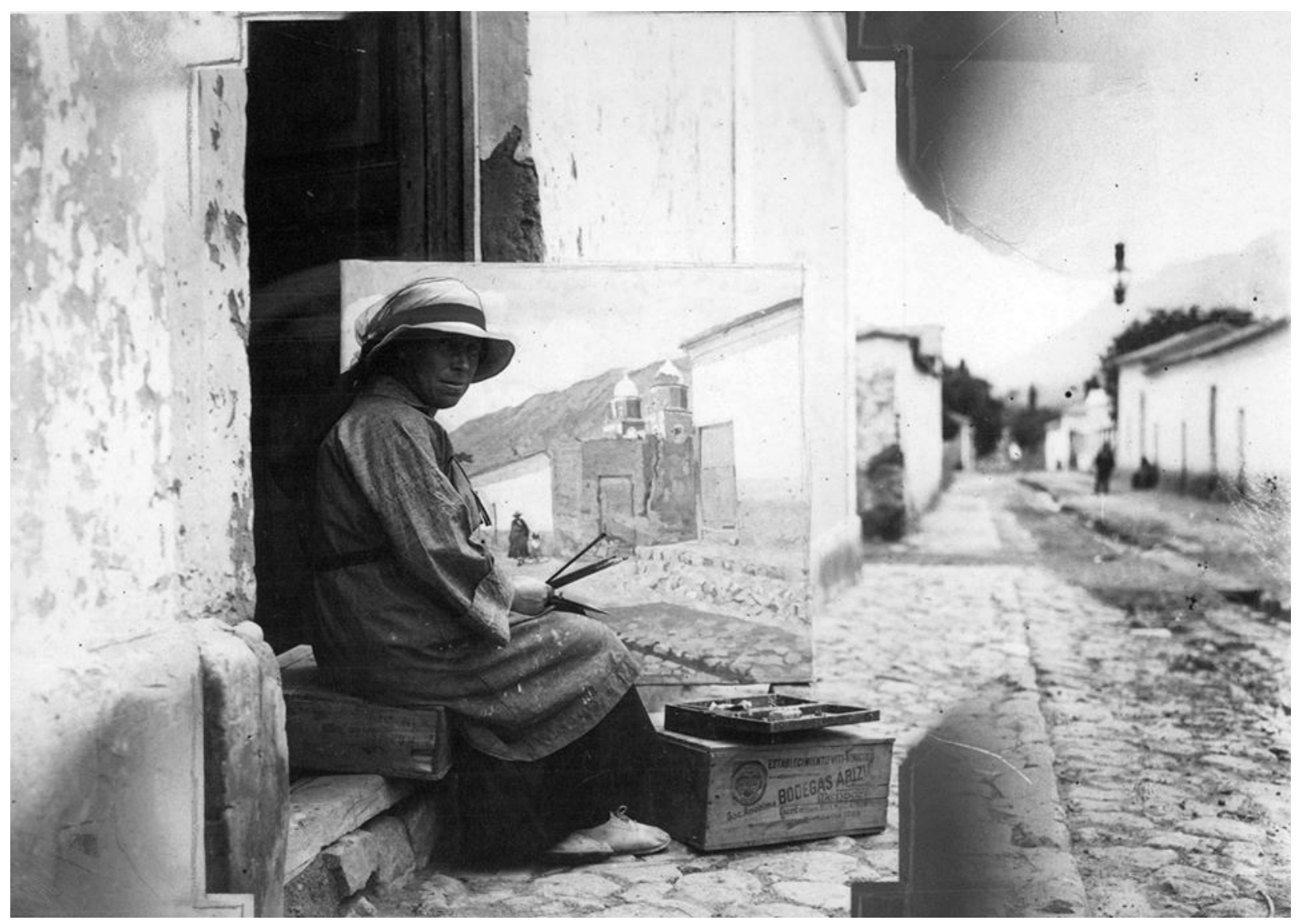

Fig. 11. Léonie Matthis pintando en Tilcara, 1924. Fotografía. Archivo Gral. de la Nación Argentina.

\section{Reflexiones finales}

El Museo de Arte Moderno fue una pieza clave en la política oficial del arte contemporáneo en España, de forma paralela a las Exposiciones Nacionales. Una institución rodeada de polémicas, con sus colecciones criticadas desde diversos sectores y una trayectoria irregular hasta 1975, debido a la alternancia política y a las diferentes concepciones sobre el arte moderno de sus respectivos directores y miembros del Patronato ${ }^{120}$.

El papel de las artistas mujeres en la institución fue minoritario en el período comprendido entre 1898 y 1936. Las 11 muestras de artistas mujeres expuestas en este trabajo representan poco más de un $7 \%$ del total de las 156 exposiciones individuales organizadas desde 1898; un número verdaderamente irrelevante pero acorde a la también minoritaria presencia femenina en la Exposición Nacional, en cuya edición de 1924 las pintoras representaban el 6,6\%; o en el Salón de Otoño, en cuya primera convocatoria de 1920 solo representaron el 5,8\% ${ }^{121}$, alcanzando el $18 \%$ en $1933^{122}$. Estos números, lamentablemente cercanos a los datos de participación femenina en las exposiciones del MNCARS en la actualidad donde, según el

\footnotetext{
120 JiMÉNEZ-BLANCO, 1989.

121 Cfr. Pilar MuÑoz, Artistas españolas en la dictadura de Franco, Sevilla, ARcibel, 2014, pp. 50-67.

122 Cfr. Tejeda y Folch, 2018, p. 22.
} 
Observatorio MAV, las artistas mujeres solo protagonizaron el 29,41\% de las muestras totales entre 2010 y $2013^{123}$, reflejan la discriminación de género que aún existe en el sistema del arte actual.

Uno de los aspectos más interesantes revelados en este trabajo ha sido el relativo a la nacionalidad de las artistas, que eran extranjeras en un $75 \%$, mientras que entre sus colegas varones, los extranjeros solo representaron el 22\%. Este dato avala el desfase español en el volumen de pintoras y escultoras profesionales, resultado del insuficiente esfuerzo en la educación y la formación artística de la mujer, al que contribuía la inexistencia de asociaciones de mujeres artistas que sí existían en Francia, Alemania, Austria o Chile, y de salones expositivos específicos, y acababa motivando la salida de pintoras españolas a París ${ }^{124}$, como hicieron M. ${ }^{a}$ Luisa de la Riva, Llüisa Vidal, Elvira Malagarriga o María Blanchard.

Los motivos que trajeron a nuestras nueve artistas extranjeras a España fueron fundamentalmente familiares y sentimentales, al haberse casado con hombres españoles, por acompañar a sus maridos en sus desplazamientos profesionales en nuestro país; o por tener raíces españolas. Escapan a esta generalidad las pintoras Ana Weiss y Léonie Matthis, que visitaron el país con un fin exclusivamente profesional, aprovechando el hermanamiento cultural entre el viejo y el nuevo continente, como también hicieron José Fiovaranti, Tito Cittadini, Álvarez Díaz, Alberto Rossi, Santos Balmori, Torres-García o Felipe Cossío del Pomar, entre otros artistas latinoamericanos expositores también en el Museo. Solo Victoria de Malinovska llegó a España sin marido o parentesco conocido, después de haber viajado por otras ciudades europeas; al igual que Nelly Harvey, Milada Sindlerová, Maxa Nordau, Bettina Giacometti, Laura Rodig, etc. Todas ellas ayudaron a visibilizar y propagar en España el nuevo modelo de mujer moderna, sirviendo de ejemplo y acicate para la profesionalización artística de las españolas.

La elevada posición social y económica que tuvieron la mayoría de las artistas profesionales del período, y/o su pertenencia a familias cultas de artistas o intelectuales que habrían favorecido su educación y su carrera artística, también se ha confirmado en el caso de las expositoras del Museo de Arte Moderno, no pasando desapercibida la relación expuesta entre la pintora Margarita Hausmann con la reina Victoria Eugenia; la amistad personal de los Bauer-Eprhussi con el rey Alfonso XIII, que compartían fiestas en la Granja, donde tenían palacios de verano; y la influencia que pudo tener el marido de Thyra Ullmann como director del Banco Transatlántico Alemán, que se había hecho con el control de la industria eléctrica y química españolas. En todo caso, de estas influencias no estarían ajenas los pintores o escultores hombres, entre los cuales también hubo expositores vinculados con las casas reales, la diplomacia y la política española o europea, como Luis Alberto de Sangróniz, Francisco Maura, Constantino de Hohenlohe, Philip de László, etc.

Sin embargo, la legitimidad y la reputación de las artistas mujeres durante el primer tercio del siglo XX no dependía tanto del estatus, como de la filiación masculina representada por sus maridos y parientes artistas o por sus maestros, a quienes los críticos atribuían siempre los logros femeninos ${ }^{125}$. El ensombrecimiento que provocaba a una mujer artista ser la esposa de un pintor reconocido, como en los casos de Daniel Vázquez Díaz sobre Eva Aggerholm y de José Frau sobre Margarita Frau, era ampliamente compensado con las mayores facilidades para integrarse en el circuito expositivo que les ofrecían. En este sentido, es muy probable que ninguna de las dos artistas señaladas hubiera expuesto en el Museo de Arte Moderno de no hacerlo conjuntamente con sus esposos, siendo la del MAM su primera y única exposición. La paulatina convivencia de mujeres y hombres en los talleres de pintores y escultores y en las academias

\footnotetext{
${ }^{123}$ MAV, Síntesis gráfica de la situación de la mujer en el sistema del arte en España, 2013 [en línea], [Consulta: 4 de enero de 2020]

124 Véase Charlote Foucher, "En busca de la emancipación. Las mujeres artistas en París en torno a 1900", en Pintoras en España 1859-1926. De María Luisa de la Riva a Maruja Mallo, Magdalena Illán Martín y Concha Lomba (comis.), Zaragoza, Universidad/Diputación de Zaragoza (catálogo de la exposición celebrada del 20 de febrero al 28 de junio de 2014), 2014, pp. 39-49. 125 Foucher, 2014, p. 44.
} 
artísticas, hizo relativamente frecuentes los matrimonios de artistas en esta época, deteniéndose esta tendencia en los años setenta ${ }^{126}$. No obstante, a tenor de lo revelado en este trabajo, no fueron tan infrecuentes las artistas solteras, como Malinowska, Valero, probablemente Hausmann y Marisa Roësset, que compartía su vida con otra mujer ${ }^{127}$; así como las mujeres casadas con hombres dedicados a otros menesteres (Ullmann y Ephrussi) y con escritores (Norah Borges). E incluso, aunque fuera poco corriente, también existieron artistas cuyo mérito superó al de sus maridos, como Léonie Matthis, cuyas vistas de la Argentina colonial siguen siendo valoradas debido a su contenido didáctico y son muy reproducidas en los libros de texto argentinos.

La ayuda de los maestros de las academias y talleres en que se formaron las pintoras y escultoras también fue fundamental para el lanzamiento de sus discípulas, gracias a su reputación y a que algunos de ellos participaban a su vez en los procesos de selección de artistas de los certámenes y exposiciones. Este apoyo, extensible igualmente a los aprendices hombres (no fueron pocos los que llegaron al MAM sin exposiciones, becas o medallas previas) pero doblemente necesario en el caso de las mujeres, no pasaba desapercibido en la crítica de arte, siendo objeto de censura el galanteo y la condescendencia con que se trataba a algunas artistas para cumplir con sus reputados profesores. A este respecto, escribía Bernardino de Pantorba, refiriéndose a las Exposiciones Nacionales, pero que podríamos extrapolar a la participación femenina en otros Salones, que "entre las obras 'rechazables', nunca escasas, que por presiones amistosas e influencias de sus autores 'salvaban' el peligro de la no admisión y pasaban a engrosar el catálogo de lo expuesto", estaban las de "los discípulos -iy las discípulas!- de maestros con alta vara en el seno del Jurado" 128 . Llevando este asunto a las expositoras del Museo de Arte Moderno, debe considerarse la previsible intermediación de Fernando Álvarez de Sotomayor, a la vez que pintor, académico y director del Museo del Prado, para que Gisela Ephrussi, alumna principiante, y en una época en que la situación económica de los Bauer empezaba a decaer, compartiera exposición con una de sus mejores discípulas, Marisa Roësset, cuya reputación ya estaba avalada con varias medallas y era compañera de taller de sus propias hijas; o el apoyo que el padre de Paula Millán, desde su puesto de dibujante en la Cátedra de Anatomía de la Facultad de Medicina de Madrid, pudo proporcionarle a través de sus contactos.

En esta red necesaria de apoyos estaban también los amigos, intelectuales, críticos de arte o colegas de profesión que confiaron en el talento de nuestras autoras. Para Malinowska, mujer sola y sin parentesco español como hemos dicho, debió ser fundamental en sus inicios el contacto con Zuloaga y los Zubiaurre. Pese a ello, en 1918 pedía ayuda a Sorolla para buscar un local donde exponer obras fáciles de vender en San Sebastián, por encontrarse necesitada de dinero para subsistir ${ }^{129}$. Más fácil debió resultarle a Maroussia Valero introducirse en el mundo artístico español, aprovechando los contactos de su padre y de su hermano escultor. El siguiente fragmento de la carta que le escribió Zuloaga tras su éxito en Salón de París en 1921, visualiza estos apoyos y el talento artístico que una mujer debía poseer para recibir ayuda:

Muy distinguida amiga mía: acabo de ver el salón; y mucha alegría me ha causado el ver que su retrato es indudablemente una de las mejores cosas que hay allí. Está muy bien y le felicito muy sinceramente. Siga sin miedo adelante. Tenga fe en su talento. Yo le prometo hacer cuanto pueda, en cuantas ocasiones se me presenten ${ }^{130}$.

Con todo, las filiaciones a las que debieron someterse las mujeres dentro de las convenciones de la época no fueron fórmulas infalibles y suficientes para conseguir una exposición en el Museo de Arte

\footnotetext{
126 TEJEDA y Folch, 2018, pp. 22-23.

127 Nuria CAPDEVIla, Artistas y precursoras. Un siglo de autoras Roësset (1882-1995), Madrid, Horas y Horas, 2013 , p. $133-134$.

128 PANtorba, 1980, p. 29, citado en MuÑoz, 2014, p. 53.

129 La carta, fechada en 1918, se conserva en el Museo Sorolla con el número de inventario CS3261.

130 Luis FRANCO DE ESPES, "Maroussia Valero, la hija de una aristócrata rusa y un artista español", Estampa, 66 (9 de abril de 1929), p. 8.
} 
Moderno. Prueba de ello es que otras pintoras de mayor éxito y recorrido que algunas de las estudiadas no tuvieron esa posibilidad. Por citar algunos casos, es llamativo que no expusieran en el Museo ninguna de las grandes pintoras de finales del XIX que todavía estaban activas en los años veinte como Julia Alcayde o María Luisa de la Riva, que poseían más de una medalla en la Exposición Nacional y en salones extranjeros. Sorprende también que no lo hiciera Nelly Harvey, retratista inglesa de gran reputación y recurrente en la Exposición Nacional, que retrató a muchos miembros de la aristocracia y la alta burguesía madrileña, incluida la reina Victoria Eugenia. Puesto que uno de los criterios de selección de los expositores era mostrar los resultados de sus estancias becadas en Europa, Roma o El Paular, como hicieron, entre otros, José Ramón Zaragoza, Juan Espina y Capo, Gregorio Prieto, García Maroto, Jesús Gallego Marquina, Agustín Olgera o Mariano Rodríguez Orgaz, etc., también resulta difícil explicar que no llegara a exponer en el Museo la paisajista madrileña María Pérez Herrero, formada en San Fernando, que recibió una pensión para ampliar estudios en la Escuela de Paisaje de El Paular y una beca para completar su formación en Europa, además de una tercera medalla en la Exposición Nacional en 1922. Lo mismo podría decirse de Maruja Mallo o Ángeles Santos, dos de las artistas de la vanguardia más laureadas en los años treinta, que encajaban a la perfección con la política expositiva del Museo en la República, donde hubo cierta inclinación hacia obras cercanas al surrealismo y a los artistas de los ADLAN ${ }^{131}$.

Las exposiciones realizadas en el Museo de Arte Moderno de Madrid no determinaron la trayectoria de las artistas estudiadas, siendo en algunos casos la única muestra individual que lograron realizar y, en otros, una entre las escasas exposiciones que, de manera intermitente, pudieron organizar mientras compaginaban sus tareas artísticas con las ocupaciones familiares, consideradas prioritarias por la ideología dominante ${ }^{132}$. Pese a ello, en un contexto todavía hostil a la emancipación de la mujer, constreñido por numerosos prejuicios sobre el talento femenino que balizaban su existencia como artistas, dichas exposiciones, realizadas en un espacio de legitimación como era un Museo Nacional, favorecieron la visibilidad a las artistas mujeres, estimulando el interés y la crítica de arte. Aun siendo minoritarias, su estudio nos ha permitido conocer mejor y, en algunos casos, descubrir, dado el silencio histórico e historiográfico vertidos sobre sus nombres, a las 12 pintoras y escultoras expuestas, y contextualizar su obra en los géneros y estilos artísticos con mayor mercado y acogida en el conservador núcleo madrileño: costumbrismos, regionalismos, impresionismos, etc. Desde dichos parámetros, algunas conciliaron tradición y modernidad al realizar sus propias aportaciones a la iconografía de la mujer moderna, aspecto visible en los autorretratos andróginos de Roësset; en los guiños que con las representaciones de folklóricas o cupletistas hacían a la vida de cabaret, más distendida que la que se permitía a una mujer burguesa; en las provocaciones a la moral que todavía resultaban los desnudos realizados por mujeres; e incluso, en sus retratos a intelectuales, con los que demostraban su participación en los ambientes culturales masculinos y sustituían el rol tradicional de mujer representada por el de mujer artista.

En definitiva, el estudio de cada una de ellas y de su paso por el Museo de Arte Moderno permite poner a la mujer artista en el centro del proceso de modernización vivida en España a partir de los años veinte ${ }^{133}$ y contribuye a visibilizar su propia modernidad, en las estrategias y negociaciones que tuvieron que desplegar para profesionalizarse y asistir a las academias de bellas artes; para realizar viajes de formación o profesionales, participar en los salones y exposiciones sobresaturadas de artistas, ejercer la docencia, conseguir contratos de ilustración, etc.

\footnotetext{
131 JiMÉNEZ-BLANCO, 1989, pp. 38-39.

132 MuÑOZ, 2014, p. 65.

133 TEJeda y Folch, 2018, p. 19.
} 
ISABEL RODRIGO VILLENA es Profesora Contratada Doctora en el Departamento de Historia del Arte de la Universidad de Castilla-La Mancha, donde actualmente imparte las asignaturas Museología, Gestión del Patrimonio Cultural y Fotografía y Cultura de Masas en el Grado de Historia del Arte. Asimismo, imparte docencia en la Facultad de Educación de Ciudad Real y es profesora en el Máster en Profesor de Educación Secundaria Obligatoria y Bachillerato, en materias vinculadas con el diseño y desarrollo curricular de la Historia del Arte. Su línea de investigación principal se sitúa en el terreno de los estudios de género, con un interés especial en el proceso de profesionalización de las mujeres artistas durante el primer tercio del siglo XX español, y en el análisis de su papel en el circuito artístico de las exposiciones y de su recepción en la crítica de arte; temas sobre los que viene contribuyendo a congresos, libros colectivos y revistas como Arenal, Asparkia, LOCVS AMOENVS, UcoArte, Quintana, etc. Una segunda línea de investigación y contribuciones científicas está dedicada a la didáctica de la Historia del Arte en general y a la difusión de la mujer en el currículo y en el Patrimonio Cultural.

Email: Isabel.Rodrigo@uclm.es

Código ORCID: https://orcid.org/0000-0002-3762-1260 